\title{
Modelling $\mathrm{CO}_{2}$ weather - why horizontal resolution matters
}

\author{
Anna Agustí-Panareda ${ }^{1}$, Michail Diamantakis ${ }^{1}$, Sébastien Massart ${ }^{1}$, Frédéric Chevallier $^{2}$, Joaquín Muñoz-Sabater ${ }^{1}$, \\ Jérôme Barré ${ }^{1}$, Roger Curcoll ${ }^{3}$, Richard Engelen ${ }^{1}$, Bavo Langerock ${ }^{4}$, Rachel M. Law ${ }^{5}$ Zoë Loh ${ }^{5}$, \\ Josep Anton Morguí ${ }^{3}$, Mark Parrington ${ }^{1}$, Vincent-Henri Peuch ${ }^{1}$, Michel Ramonet ${ }^{2}$, Coleen Roehl ${ }^{6}$, \\ Alex T. Vermeulen ${ }^{7}$, Thorsten Warneke ${ }^{8}$, and Debra Wunch ${ }^{9}$ \\ ${ }^{1}$ European Centre for Medium-Range Weather Forecasts, Shinfield Park, Reading, RG2 9AX, UK \\ ${ }^{2}$ Laboratoire des Sciences du Climat et de l'Environnement, LSCE/IPSL, CEA-CNRS-UVSQ, Université Paris-Saclay, \\ 91198 Gif-sur-Yvette, France \\ ${ }^{3}$ Environmental Science and Technology Institute, Universitat Autònoma de Barcelona, ICTA-UAB, Bellaterra, Spain \\ ${ }^{4}$ Royal Belgian Institute for Space Aeronomy (BIRA-IASB), Brussels, Belgium \\ ${ }^{5}$ CSIRO Oceans and Atmosphere, PMB 1, Aspendale, Victoria 3195, Australia \\ ${ }^{6}$ California Institute of Technology, Pasadena, California, USA \\ ${ }^{7}$ ICOS ERIC Carbon Portal, Sölvegatan 12, 22362 Lund, Sweden \\ ${ }^{8}$ University of Bremen, Institute of Environmental Physics, Otto-Hahn-Allee 1, 28359 Bremen, Germany \\ ${ }^{9}$ University of Toronto, Department of Physics, Toronto, Ontario, Canada
}

Correspondence: Anna Agustí-Panareda (anna.agusti-panareda@ecmwf.int)

Received: 20 February 2019 - Discussion started: 27 February 2019

Revised: 7 May 2019 - Accepted: 8 May 2019 - Published: 4 June 2019

\begin{abstract}
Climate change mitigation efforts require information on the current greenhouse gas atmospheric concentrations and their sources and sinks. Carbon dioxide $\left(\mathrm{CO}_{2}\right)$ is the most abundant anthropogenic greenhouse gas. Its variability in the atmosphere is modulated by the synergy between weather and $\mathrm{CO}_{2}$ surface fluxes, often referred to as $\mathrm{CO}_{2}$ weather. It is interpreted with the help of global or regional numerical transport models, with horizontal resolutions ranging from a few hundreds of kilometres to a few kilometres. Changes in the model horizontal resolution affect not only atmospheric transport but also the representation of topography and surface $\mathrm{CO}_{2}$ fluxes. This paper assesses the impact of horizontal resolution on the simulated atmospheric $\mathrm{CO}_{2}$ variability with a numerical weather prediction model. The simulations are performed using the Copernicus Atmosphere Monitoring Service (CAMS) $\mathrm{CO}_{2}$ forecasting system at different resolutions from 9 to $80 \mathrm{~km}$ and are evaluated using in situ atmospheric surface measurements and atmospheric column-mean observations of $\mathrm{CO}_{2}$, as well as radiosonde and SYNOP observations of the winds.

The results indicate that both diurnal and day-to-day variability of atmospheric $\mathrm{CO}_{2}$ are generally better represented at high resolution, as shown by a reduction in the errors in sim-
\end{abstract}

ulated wind and $\mathrm{CO}_{2}$. Mountain stations display the largest improvements at high resolution as they directly benefit from the more realistic orography. In addition, the $\mathrm{CO}_{2}$ spatial gradients are generally improved with increasing resolution for both stations near the surface and those observing the total column, as the overall inter-station error is also reduced in magnitude. However, close to emission hotspots, the high resolution can also lead to a deterioration of the simulation skill, highlighting uncertainties in the high-resolution fluxes that are more diffuse at lower resolutions.

We conclude that increasing horizontal resolution matters for modelling $\mathrm{CO}_{2}$ weather because it has the potential to bring together improvements in the surface representation of both winds and $\mathrm{CO}_{2}$ fluxes, as well as an expected reduction in numerical errors of transport. Modelling applications like atmospheric inversion systems to estimate surface fluxes will only be able to benefit fully from upgrades in horizontal resolution if the topography, winds and prior flux distribution are also upgraded accordingly. It is clear from the results that an additional increase in resolution might reduce errors even further. However, the horizontal resolution sensitivity tests indicate that the change in the $\mathrm{CO}_{2}$ and wind modelling error 
with resolution is not linear, making it difficult to quantify the improvement beyond the tested resolutions.

Finally, we show that the high-resolution simulations are useful for the assessment of the small-scale variability of $\mathrm{CO}_{2}$ which cannot be represented in coarser-resolution models. These representativeness errors need to be considered when assimilating in situ data and high-resolution satellite data such as Greenhouse gases Observing Satellite (GOSAT), Orbiting Carbon Observatory-2 (OCO-2), the Chinese Carbon Dioxide Observation Satellite Mission (TanSat) and future missions such as the Geostationary Carbon Observatory (GeoCarb) and the Sentinel satellite constellation for $\mathrm{CO}_{2}$. For these reasons, the high-resolution $\mathrm{CO}_{2}$ simulations provided by the CAMS in real time can be useful to estimate such small-scale variability in real time, as well as providing boundary conditions for regional modelling studies and supporting field experiments.

\section{Introduction}

Over synoptic weather timescales of hours to days and spatial scales less than $1000 \mathrm{~km}$, the assumption that atmospheric $\mathrm{CO}_{2}$ is well-mixed into a homogeneous background does not hold, as shown by the observed variability at baseline in situ stations (e.g. Halter and Harris, 1983). $\mathrm{CO}_{2}$ weather is defined here as the atmospheric $\mathrm{CO}_{2}$ variability at timescales and spatial scales of weather systems (Parazoo et al., 2011) as depicted in Fig. 1. It reflects a complex combination of anthropogenic and natural $\mathrm{CO}_{2}$ fluxes near the Earth's surface and transport by weather systems in the atmosphere (Geels et al., 2004; Patra et al., 2008). This synergy of $\mathrm{CO}_{2}$ fluxes and weather results in intricate atmospheric $\mathrm{CO}_{2}$ patterns of positive and negative anomalies, collocated with weather variations on top of the well-mixed $\mathrm{CO}_{2}$ background that varies slowly on timescales of weeks to years (Keeling et al., 1976).

Modelling the synoptic-scale transport that modulates the $\mathrm{CO}_{2}$ weather is crucial for interpreting the variability of surface $\mathrm{CO}_{2}$ concentrations from in situ observations (Law et al., 2010) and column-averaged $\mathrm{CO}_{2}$ from satellite and ground-based observations (Corbin et al., 2008) and for forecasting $\mathrm{CO}_{2}$ from 1 to $10 \mathrm{~d}$ ahead (Agustí-Panareda et al., 2014; Tang et al., 2018) in order to examine the predictive skill of the models. Tracer transport models use the numerical schemes and meteorological information of numerical weather prediction (NWP) to simulate the tracer variability in the atmosphere. Increasing the horizontal resolution associated with the grid spacing of tracer transport models has the benefit of reducing the numerical errors in tracer simulations, leading to convergence of the transport solution from different transport schemes (Prather et al., 2008). NWP models for weather forecasting have been doubling the global horizontal resolution approximately every 8 years (Wedi, 2014) in order to improve the forecast skill. But until now, global tracer transport models have generally used lower resolution than NWP models, as chemical transport models including chemistry and/or long window data assimilation cannot afford such computational expense.

Observations of atmospheric $\mathrm{CO}_{2}$ are used in data assimilation systems based on tracer transport models to produce optimal estimates of atmospheric $\mathrm{CO}_{2}$ concentrations (e.g. Massart et al., 2016) or model parameters and $\mathrm{CO}_{2}$ fluxes in atmospheric inversion systems (e.g. Rayner et al., 2005; Chevallier et al., 2010). If tracer transport models cannot represent the synoptic variability accurately, then the resulting errors when comparing the tracer from the model with observations will prevent these observations from being used effectively in the data assimilation systems (e.g. Brooks et al., 2012). The model-observation mismatch caused by differences in the resolution of the tracer transport model - including both the resolution of the meteorological fields and the resolution of the fluxes on the model grid - and the resolution of the observation footprint is also known as representativeness error. Failure to properly account for representativeness errors in data assimilation will lead to errors in the optimised parameters, whether atmospheric concentrations, model parameters or surface fluxes.

Several studies have investigated the spatial representativeness errors of $\mathrm{CO}_{2}$ (Miller et al., 2007; van der Molen and Dolman, 2007; Corbin et al., 2008; Tolk et al., 2008) by analysing the $\mathrm{CO}_{2}$ distribution within model grid cells, based on nested high-resolution simulations on limited domains over Europe, North America and South America for certain months or by statistical parameterisation of $\mathrm{CO}_{2}$ covariances based on lower-resolution simulations (Alkhaled et al., 2008). The importance of high resolution over complex terrain has also been demonstrated on regional scales, e.g. in Europe (van der Molen and Dolman, 2007; Ahmadov et al., 2009; Pillai et al., 2011) and in North America (Lin et al., 2017; Hedelius et al., 2017) using very high resolution simulations (down to $1 \mathrm{~km}$ ). However, other studies with coarser global tracer transport models have compared $\mathrm{CO}_{2}$ simulations with a range of resolutions from a few degrees down to $0.5^{\circ}$ without finding significant improvements with respect to observations (Lin et al., 2018; Remaud et al., 2018).

The full impact of horizontal resolution on the simulated tracer variability depends on the resolution of transport and emissions/biogenic fluxes (e.g. Vogel et al., 2013) as well as the resolution of the topography and the winds (e.g. Sekiyama et al., 2015) in the model. In this study the full sensitivity of $\mathrm{CO}_{2}$ synoptic variability to the model horizonal resolution (including all the aspects mentioned above) is investigated by quantifying the change in model error with horizontal resolution at observing stations. Three main questions are addressed: 
(a) $2014011512: 00$ UTC

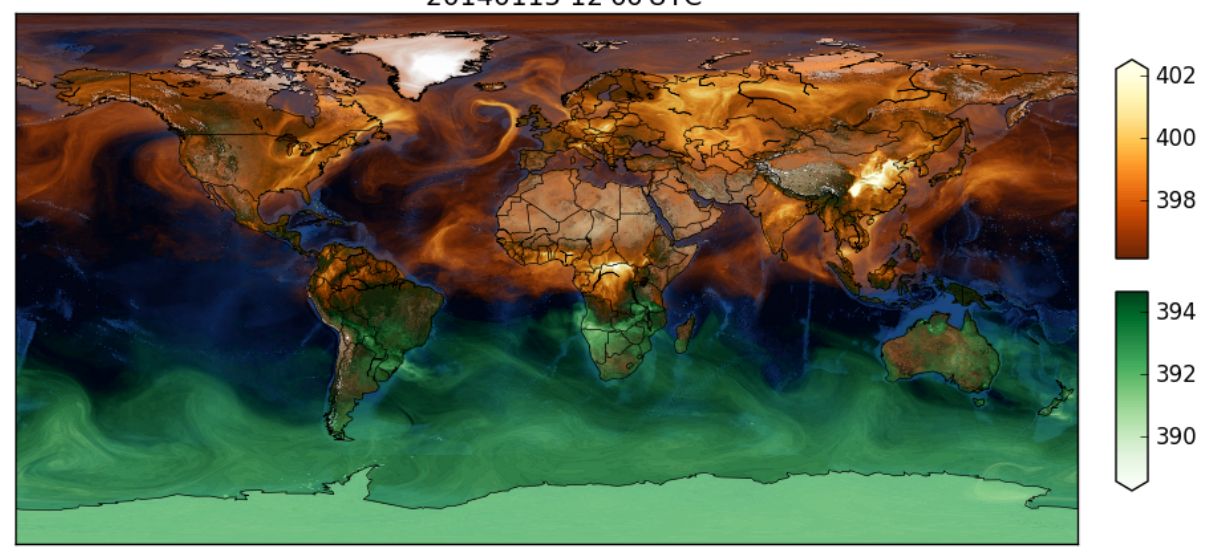

(b) 20140715 12:00 UTC

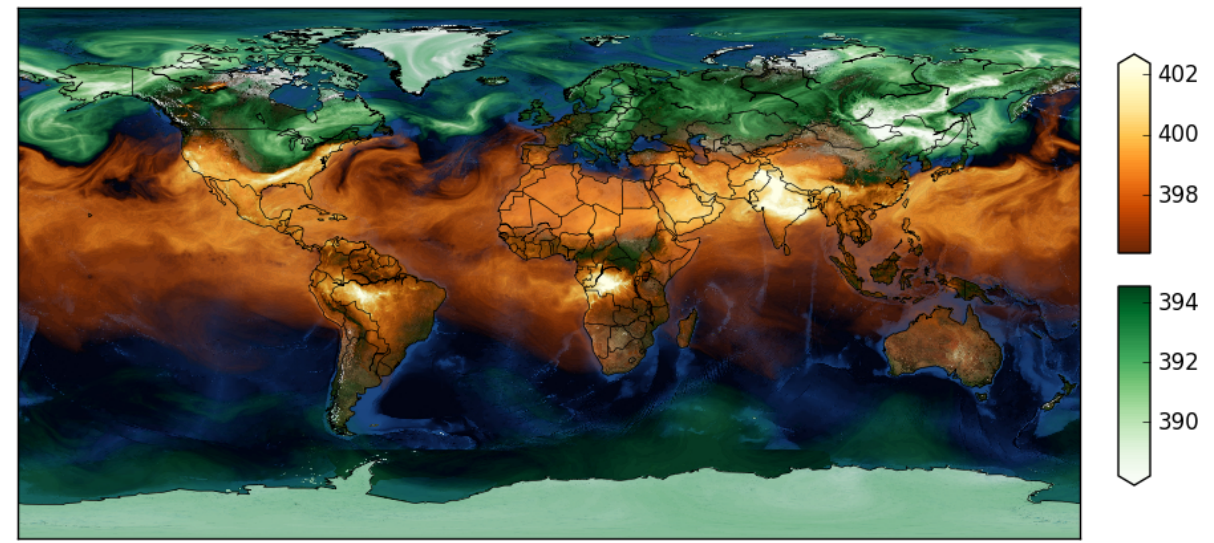

Figure 1. Snapshots of column-averaged $\mathrm{CO}_{2}\left(\mathrm{XCO}_{2}\right)(\mathrm{ppm})$ above (in reds) and below (in greens) the global mean on $15 \mathrm{January}(\mathrm{a})$ and 15 July (b) at 12:00 UTC from the Copernicus Atmosphere Monitoring Service global $\mathrm{CO}_{2}$ forecast at high horizontal resolution $(\sim 9 \mathrm{~km})$.

1. What is the sensitivity of the modelled atmospheric $\mathrm{CO}_{2}$ variability at diurnal and synoptic timescales to horizonal resolution?

2. How is horizontal resolution affecting the mediumrange (1-10d) forecast error growth of atmospheric $\mathrm{CO}_{2}$ ?

3. What are the typical $\mathrm{CO}_{2}$ representativeness errors in models with horizontal resolutions of $1^{\circ} \times 1^{\circ}$, currently considered as high resolution in tracer transport models, and where and when are these representativeness errors largest?

The model simulations use the operational Copernicus Atmosphere Monitoring Service (CAMS) global $\mathrm{CO}_{2}$ forecasting system (Agustí-Panareda et al., 2014; Massart et al., 2016) which is based on the Integrated Forecasting System (IFS) model of the European Centre for Medium-Range Weather Forecasts (ECMWF). They are performed over a range of resolutions currently used operationally in NWP from 9 to $80 \mathrm{~km}$. A detailed description of the simulations, observations and tools used to assess the importance of horizontal resolution for simulating atmospheric $\mathrm{CO}_{2}$ variability related to weather is presented in Sect. 2. Section 3 shows the impact of horizontal resolution on the error of simulated horizontal winds (Sect. 3.1) and atmospheric $\mathrm{CO}_{2}$ (Sect. 3.2 and 3.3). The results of the sensitivity to horizontal resolution are explained in the context of the small-scale variability in Sect. 3.4. The diagnostics of small-scale variability provide an estimate of the expected representativeness errors for $\mathrm{CO}_{2}$ simulations with coarser horizontal resolutions. Finally, an example of an urban site is shown in Sect. 3.5, where the impact of horizontal resolution is positive in January and negative in July. The implications of the results for $\mathrm{CO}_{2}$ forecasting and atmospheric inversion systems are discussed in Sect. 4, with a summary of the main findings on why and where horizontal resolution matters. 


\section{Methodology}

\subsection{Observations}

Continuous in situ observations near the surface and columnaveraged observations from the Total Carbon Column Observing Network (TCCON) provide the reference for atmospheric $\mathrm{CO}_{2}$ variability. Figure 2 shows the spatial distribution of the $\mathrm{CO}_{2}$ observing stations used in this study. Hourly near-surface $\mathrm{CO}_{2}$ observations are provided by 51 in situ stations operated by various organisations throughout the period of the simulations: data from 44 stations are taken from the cooperative GLOBALVIEWplus (ObsPack , 2015) data set, and additional data have been obtained from three additional stations from CSIRO in Australia and Antarctica and four stations from the ClimaDat network (Morguí et al., 2013, 2017) over the Iberian Peninsula. The cooperative GLOBALVIEWplus (ObsPack , 2015) data set is coordinated by NOAA, and it comprises data collected by various institutions and laboratories including AEMET, AGH, CSIRO, ECCC, ECN, EMPA,FMI, HMS, LSCE, NCAR, NOAA, JMA, NIWA, SAWS, TU, UBA-SCHAU, UEA, UHEI-IUP and UR (see Tables A1 and A2 for full list of stations with their organisations and associated references). No selection criteria are applied to the stations from the GLOBALVIEWplus ObsPack (2015), CSIRO and ClimaDat data sets, other than availability of hourly data for January and July 2014.

Most stations are on the World Meteorological Organization (WMO) $\mathrm{CO}_{2}$ scale, although the inter-calibration of standard gases is not critical for this study because the focus is on the relative difference between the high- and lowresolution simulations to quantify the sensitivity of modelled $\mathrm{CO}_{2}$ to horizontal resolution in the model. The distribution of the stations is not homogeneous over the globe. However, there is a wide variety of locations that sample synoptic variability on various types of terrain including many coastal, mountain, continental and oceanic sites over different continents on both hemispheres. Wind observations from around 400 radiosondes stations and all the operational $10 \mathrm{~m}$ SYNOP stations around the globe are used to evaluate the sensitivity of wind errors to the model horizontal resolution at different atmospheric levels in the troposphere.

Total column observations from 18 TCCON Fourier transform spectrometers (FTSs) (Wunch et al., 2011) available in January and July 2014 - shown as red triangles in Fig. 2 - are also used to evaluate the variability of the column-averaged dry-air mole fraction of $\mathrm{CO}_{2}$ - hereafter referred to as $\mathrm{XCO}_{2}$ - (Table A3). These TCCON observations are retrieved from direct solar near-infrared spectra (http://www.tccon.caltech. edu, last access: 30 May 2019), and they provide a ground reference to the GOSAT (Kuze et al., 2009), OCO-2 (Crisp et al., 2017) and TanSat (Yang et al., 2018) satellite observations (e.g. Inoue et al., 2016; Wunch et al., 2017). Total column averages are less sensitive to the uncertainties associated with vertical mixing than the $\mathrm{CO}_{2}$ abundances near the surface. However, the temporal coverage of TCCON observations is limited to clear-sky and sunny conditions, which means there are generally more gaps in the TCCON data than in near-surface in situ data.

\subsection{Global atmospheric $\mathrm{CO}_{2}$ model}

The model used in this study is the Integrated Forecasting System (IFS), the same model used in NWP at ECMWF and in the CAMS atmospheric composition analysis and forecasting system to issue $5 \mathrm{~d} \mathrm{CO}_{2}$ and $\mathrm{CH}_{4}$ forecasts (https://atmosphere.copernicus.eu/charts/ cams/carbon-dioxide-forecasts, last access: 30 May 2019), as well as reactive gases and aerosol forecasts relevant for air quality (Flemming et al., 2015; Morcrette et al., 2009). The IFS model version is CY43r1, the operational weather forecast model at ECMWF from 22 November 2016 to 10 July 2017. A full evaluation of this model cycle can be found in Haiden et al. (2017). The high horizontal resolution is based on a cubic octahedral reduced Gaussian - called hereafter octahedral - grid (Holm et al., 2016). The implementation of the octahedral grid has allowed a substantial increase in the grid point resolution from $16 \mathrm{~km}$ to approximately $9 \mathrm{~km}$, without having to increase the spectral resolution of the model (Malardel et al., 2016). The 9kmEXP simulation comprises up to 904 million model grid points, 137 levels and a time step of $7.5 \mathrm{~min}$.

The tracer transport is modelled by three different numerical schemes to represent (i) the resolved advection of $\mathrm{CO}_{2}$ by the winds, and the sub-grid-scale (ii) convection and (iii) turbulent mixing processes that need to be parameterised. The tracer advection is computed using a semi-implicit semiLagrangian scheme (Temperton et al., 2001; Diamantakis and Magnusson, 2016) which is an unconditionally stable method for the integration of the transport equations and for the fast terms associated with gravity waves. SemiLagrangian advection schemes have small dispersion and phase speed errors despite using long time steps (Staniforth and Côté, 1991). In practice, these properties mean that the time step is limited only by the local truncation error and not by numerical stability bounds. The semi-Lagrangian advection scheme in the IFS is not mass-conserving. Thus, a mass fixer is required to ensure mass conservation at every time step (Agustí-Panareda et al., 2017; Diamantakis and Agustí-Panareda, 2017). The turbulent mixing scheme is described in Beljaars and Viterbo (1998), Koehler et al. (2011) and Sandu et al. (2013). The convection scheme is based on Tiedtke (1989) (see Bechtold et al., 2008, 2014, for further details). Full documentation of the IFS can be found at https: //www.ecmwf.int/en/forecasts/documentation-and-support/ changes-ecmwf-model/ifs-documentation (last access: 30 May 2019).

The $\mathrm{CO}_{2}$ surface fluxes from the ocean, biomass burning and anthropogenic emissions are prescribed using inventories or climatologies, while the biogenic fluxes over land 


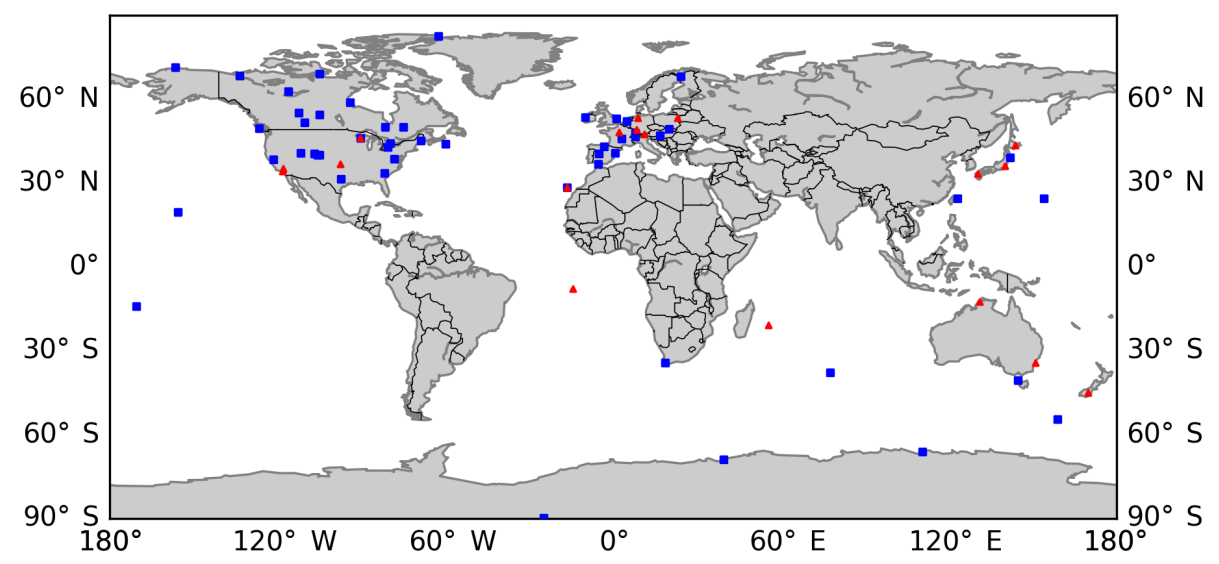

Figure 2. Map of in situ (blue squares) and TCCON (red triangles) stations. Detailed information on each station is provided in Tables A1 and $\mathrm{A} 3$.

are modelled online (see Table 1). The anthropogenic $\mathrm{CO}_{2}$ emissions come from the EDGAR v4.2 FT2010 inventory for 2012 (last year with gridded emissions). They are extrapolated in time to the year of the simulation with country trends provided by the EDGAR database (http://edgar. jrc.ec.europa.eu, last access: 30 May 2019). The biogenic $\mathrm{CO}_{2}$ emissions from land vegetation are modelled with the A-gs photosynthesis scheme and an empirical model to simulate the ecosystem respiration fluxes which are integrated in the CHTESSEL land surface model of the IFS (Boussetta et al., 2013). The fluxes have been evaluated with FLUXNET data and compared to different models (e.g. CASA and ORCHIDEE) showing a comparable performance on synoptic to seasonal scales (Balzarolo et al., 2014). An online bias correction scheme (Agustí-Panareda et al., 2016) is applied to the modelled gross primary production (GPP) and ecosystem respiration (Reco) fluxes to correct for biases in the net ecosystem exchange (NEE) budget on a timescale of $10 \mathrm{~d}$ compared to a climatology of optimised fluxes (Chevallier et al., 2010). Figure S1 in the Supplement shows the monthly mean NEE for the highest and lowest resolutions.

The atmospheric tracer transport and $\mathrm{CO}_{2}$ biogenic fluxes are two of the largest contributors to the synoptic variability of atmospheric $\mathrm{CO}_{2}$ globally (Geels et al., 2004; AgustíPanareda et al., 2014). Thus, the modelling of these two components online in the IFS allows us to investigate the full impact of the resolution coming from the winds and the tracer transport, as well as the fluxes.

\subsection{Global atmospheric $\mathrm{CO}_{2}$ simulations}

A set of global simulations are performed at several resolutions from 9 to $80 \mathrm{~km}$ (Table 2) to investigate the impact of horizontal resolution on the modelled $\mathrm{CO}_{2}$ variability at diurnal and synoptic scales. These are the resolutions that are currently used operationally in global meteorological reanalysis - e.g. ERA-Interim at $80 \mathrm{~km}$ (Dee et al., 2011) - widely used in tracer transport models and the typically higher resolutions of operational weather forecasts models. For instance, the deterministic weather forecast at ECMWF currently runs at $9 \mathrm{~km}$ resolution, and it was the global forecasting system with the highest resolution in the world when it was introduced on 8 March 2016 (Holm et al., 2016).

The octahedral grid is used for all simulations, except for the lowest-resolution simulation at $80 \mathrm{~km}$ which uses a reduced linear Gaussian grid as in the ERA-Interim and CAMS Reanalysis (Inness et al., 2019). The time steps are also dependent on the horizontal resolution and range from 7.5 to $45 \mathrm{~min}$. As described in Sect. 2.2, the semi-implicit semiLagrangian method used in the IFS is free from stability restrictions. Thus, the model uses the longest possible time step that provides the most accurate result for each spatial resolution. This is selected through experimentation and validation, but a rule of thumb is that as the horizontal resolution increases, the time step decreases to keep the mean Courant-Friedrichs-Lewy (CFL) number constant. This typically leads to much longer time steps than Eulerian models for which their time step is restricted by the typical CFL stability limit (i.e. the maximum CFL number being less than $1)$.

All the simulation experiments are conducted for a winter and a summer month, in January and July 2014, as we expect that winter and summer periods will show markedly different variability patterns in $\mathrm{CO}_{2}$. Figure 3 shows the configuration of the simulations. A $10 \mathrm{~d}$ forecast is performed at 00:00 UTC each day of the month. The meteorological initial conditions of each forecast come from the ECMWF operational NWP analysis (Rabier et al., 2000), whereas the atmospheric $\mathrm{CO}_{2}$ tracer is initialised with the previous $1 \mathrm{~d}$ forecast, which means $\mathrm{CO}_{2}$ is essentially free-running, as in Agustí-Panareda et al. (2014). The first initial conditions for $\mathrm{CO}_{2}$ on 1 January and 1 July 2014 are extracted from the CAMS $\mathrm{CO}_{2}$ analysis (Massart et al., 2016). NWP analysis of meteorological fields is one of the main elements determin- 
Table 1. Datasets and models of $\mathrm{CO}_{2}$ fluxes used in simulations listed in Table 2.

\begin{tabular}{|c|c|c|c|c|}
\hline Flux type & Source & $\begin{array}{l}\text { Temporal } \\
\text { resolution }\end{array}$ & $\begin{array}{l}\text { Resolution } \\
\text { (lat } \times \text { long.) }\end{array}$ & Reference \\
\hline Anthropogenic & EDGAR v4.2 FT2010 & Annual mean & $0.1^{\circ} \times 0.1^{\circ}$ & Olivier and Janssens-Maenhout (2015) \\
\hline Biomass burning & GFAS & Daily mean & $0.1^{\circ} \times 0.1^{\circ}$ & Kaiser et al. (2012) \\
\hline Ocean & Takahashi climatology & Monthly mean & $4.0^{\circ} \times 5.0^{\circ}$ & Takahashi et al. (2009) \\
\hline NEE & CHTESSEL & $\begin{array}{l}\text { Adapted to } \\
\text { model time step }\end{array}$ & $\begin{array}{l}\text { Adapted to } \\
\text { model resolution }\end{array}$ & $\begin{array}{l}\text { Boussetta et al. (2013), } \\
\text { Agustí-Panareda et al. (2016) }\end{array}$ \\
\hline
\end{tabular}

Table 2. List of simulations with different resolutions given by different model grids. All simulations use 137 vertical model levels. All the experiments have been performed in January and July 2014 using the same $\mathrm{CO}_{2}$ surface fluxes (see Table 1).

\begin{tabular}{lrlr}
\hline Experiment & $\begin{array}{r}\text { Model } \\
\text { resolution }\end{array}$ & Model grid & $\begin{array}{r}\text { Model } \\
\text { time step }\end{array}$ \\
\hline $9 \mathrm{kmEXP}$ & $9 \mathrm{~km}$ & Tco1279 & $7.5 \mathrm{~min}$ \\
$16 \mathrm{kmEXP}$ & $16 \mathrm{~km}$ & Tco639 & $12 \mathrm{~min}$ \\
$25 \mathrm{kmEXP}$ & $25 \mathrm{~km}$ & Tco399 & $15 \mathrm{~min}$ \\
$40 \mathrm{kmEXP}$ & $40 \mathrm{~km}$ & Tco255 & $20 \mathrm{~min}$ \\
$80 \mathrm{kmEXP}$ & $80 \mathrm{~km}$ & T1255 & $45 \mathrm{~min}$ \\
\hline
\end{tabular}

ing the quality of the tracer transport (Locatelli et al., 2013; Polavarapu et al., 2016). Keeping the meteorological fields close to the analysis by having a sequence of $1 \mathrm{~d}$ forecasts ensures the tracer transport is as realistic as possible. Therefore, the sequence of $1 \mathrm{~d}$ forecasts is used as the standard (cyclic forecast) configuration for the simulations at different resolutions.

The extension to the $10 \mathrm{~d}$ forecasts allows us to assess the impact of errors in the meteorological fields - which grow during the forecast - on the $\mathrm{CO}_{2}$ simulations. There are 10 realisations of $\mathrm{CO}_{2}$ for each day, one for each forecast lead time (Fig. 3). Each forecast lead time is evaluated separately in order to estimate the error growth during the forecast. For consistency in the evaluation of the different forecast lead times, the periods from 10 January to 10 February and 10 July to 10 August are used in the validation diagnostics.

The simulations also include an additional $\mathrm{CO}_{2}$ tracer which is only transported (i.e. does not respond to $\mathrm{CO}_{2}$ surface fluxes) during the forecast. We refer to this tracer as NFX. This tracer is still initialised with the standard $\mathrm{CO}_{2}$ at the beginning of each forecast. The difference between the NFX $\mathrm{CO}_{2}$ and the standard $\mathrm{CO}_{2}$ tracers can provide insight into the sensitivity to local flux at different horizontal resolutions. Similarly, the change in the error of the simulation with resolution for both the standard and the NFX tracers can be used as an indicator of transport versus local flux influence in the assessment of the impact of horizontal resolution.

\subsection{Diagnostics for model evaluation}

The focus of this paper is on assessing the skill of the model in simulating $\mathrm{CO}_{2}$ weather with short-term variability over a period of a month. For this purpose, the root mean square error

$\mathrm{RMSE}=\sqrt{\frac{1}{N} \sum_{i=1}^{N}\left(m_{i}-o_{i}\right)^{2}}$,

the systematic error or bias

$\mu=\frac{1}{N} \sum_{i=1}^{N}\left(m_{i}-o_{i}\right)$

and the random error

STDE $=\sqrt{\frac{1}{N} \sum_{i=1}^{N}\left(m_{i}-o_{i}-\mu\right)^{2}}$

of the modelled $\mathrm{CO}_{2}$ dry molar fraction $(\mathrm{m})$ are computed with respect to $N$ hourly observations $(o$ ) at each observing site. The standard deviation of the site error - also known as inter-station error - is used as an indicator of the spatial variability of the error $e$ (e.g. RMSE, $\mu$ ) between the $M$ observing sites:

$\sigma_{e}=\sqrt{\frac{1}{M-1} \sum_{s=1}^{M}\left(e_{s}-\bar{e}\right)^{2}}$,

where $\bar{e}$ is the mean error of all sites. It reflects the skill of the model in representing spatial gradients between the sites. The Pearson's correlation coefficient is also used to assess the skill of the model in simulating the diurnal and synoptic variability at the sites.

The model is sampled in the horizontal by taking the nearest grid point to the station over land. This approach is widely used in model evaluation (Patra et al., 2008) as it allows assessment of the model directly at grid point scale. At coastal locations, coarse-resolution models can find a better fit to observations by sampling the nearest ocean grid point as land grid points tend to overestimate the diurnal cycle (Law et al., 


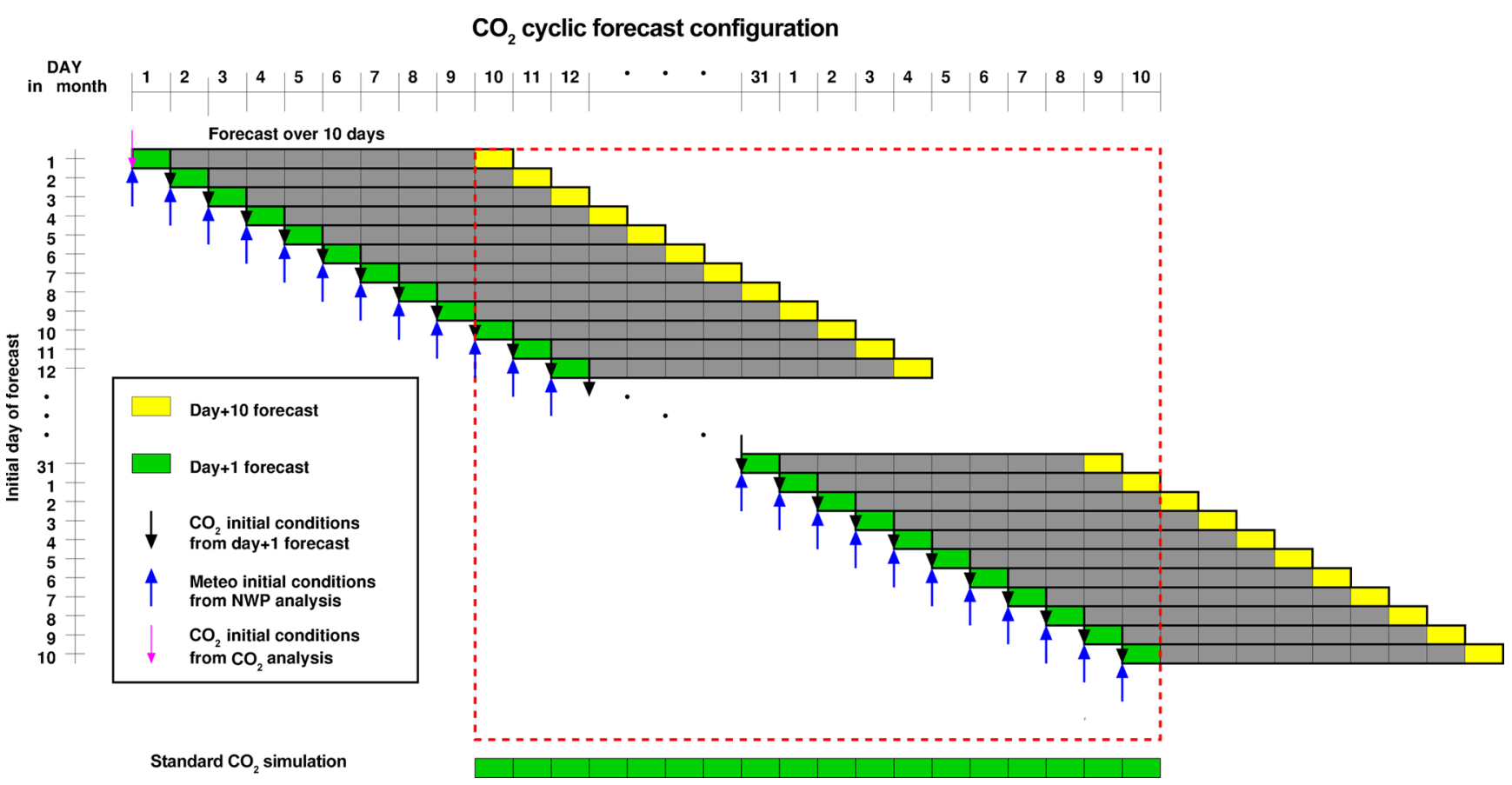

Figure 3. Schematic of $\mathrm{CO}_{2}$ simulations with cyclic forecast configuration with $10 \mathrm{~d}$ forecasts initialised every day from 1 st of the month to the 10th day of the following month. Initial conditions are depicted by arrows (see legend), and the period of evaluation in which several forecast lead times can be compared is delimited by the red dashed line. The standard $\mathrm{CO}_{2}$ simulations are composed by a series of $1 \mathrm{~d}$ forecasts as shown by the green rectangles.

2010). For this reason, the sampling protocol for observations in the atmospheric inversion system moves some stations offshore (Gurney et al., 2003). However, coastal sites can be influenced by both ocean and land, which means that they will have contrasting periods sampling baseline air associated with low variability and periods with land and local influences associated with high $\mathrm{CO}_{2}$ variability (Patra et al., 2008). In this study we have chosen to consistently sample the nearest land point over land because we are interested in assessing the capabilities of the model to represent both baseline and local influences. The temporal sampling is performed with a linear interpolation from the 3-hourly archived model fields to the observation time as in Agustí-Panareda et al. (2014).

At the surface stations, the model is also interpolated to the altitude of the sampling height above ground level (a.g.l.). This ensures the same model levels are used for the different horizontal resolutions. The model has hybrid coordinates that follow the terrain close to the surface. Selecting the model level at the station height above mean sea level (a.m.s.l.) would imply the use of different model levels for different resolutions when the orographic height varies between the horizontal resolutions. It would therefore lead to comparisons of $\mathrm{CO}_{2}$ in the planetary boundary layer and free troposphere at mountain sites where the low-resolution model underestimates the orographic height. Lin et al. (2017) tested both approaches at several mountain sites. They found that the sampling at a.m.s.l. greatly underestimates the amplitude of the diurnal cycle, as the sensitivity to local fluxes is reduced at higher levels above the ground. Since most low-resolution models used in atmospheric inversions tend to use the model sampling a.m.s.l. at mountain sites (e.g. Wang et al., 2018), a comparison of the two approaches (a.g.l. and a.m.s.l.) is provided in the Supplement. At the TCCON stations, the model profile is processed with the TCCON averaging kernel and prior, as described in Appendix A of Massart et al. (2016).

Atmospheric $\mathrm{CO}_{2}$ variability is subject to local- or smallscale influences $(<100 \mathrm{~km})$ associated with complex topography, coastal boundaries, local fluxes and mesoscale atmospheric flow (Lin, 2007). Most models used in carbon cycle studies are unable to represent such local variability. The resulting representativeness errors reflect the sub-grid-scale variability associated with the coarse resolution of the models (e.g. Tolk et al., 2008). At high resolution it is possible to estimate part of this sub-grid-scale variability of coarser models. In order to do that, the $9 \mathrm{kmEXP}$ simulation is interpolated onto a $0.1^{\circ} \times 0.1^{\circ}$ regular lat-long. grid, and subsequently it is sampled for each time zone (computed hourly along longitude) at 13:00 $\pm 0.5 \mathrm{~h}$ local time. This temporal sampling at 13:00 is consistent with the GOSAT (http://www. gosat.nies.go.jp/en/, last access: 30 May 2019) and OCO-2 (http://oco.jpl.nasa.gov/mission, last access: 30 May 2019) overpass time. Thus, it provides a more relevant estimate 
of the potential representativeness error for lower-resolution inversion systems, which use daytime surface in situ data and satellite data (e.g. Chevallier et al., 2010, 2014). The representativeness error is estimated by computing the standard deviation of the $\mathrm{CO}_{2}$ dry molar fraction at $0.1^{\circ}$ resolution within the coarser grid boxes of $1^{\circ} \times 1^{\circ}$ over the whole globe:

$\sigma_{\mathrm{CO}_{2}}=\sqrt{\frac{1}{n-1} \sum_{j=1}^{n}\left(m_{j}-\bar{m}\right)^{2}}$,

where $\bar{m}=\frac{1}{n} \sum_{j=1}^{n} m_{j} ; n$ is the number of $0.1^{\circ}$ resolution grid cells within the coarser grid cell of $1^{\circ} \times 1^{\circ} ; m$ is the $\mathrm{CO}_{2}$ dry molar fraction at $0.1^{\circ}$ resolution; and $\bar{m}$ is the average within the coarser grid cell.

\section{Results}

\subsection{Impact of horizontal resolution on winds}

The accuracy of the winds is a crucial aspect of the $\mathrm{CO}_{2}$ transport quality, as winds drive the advection of $\mathrm{CO}_{2}$ across the resolved gradients in the model. In this section we investigate the benefit of increasing the resolution from 80 to $9 \mathrm{~km}$ on the RMSE of the zonal and meridional components of the wind. We investigate the changes in the global wind error with model resolution based on 12-hourly radiosonde observations which measure the horizontal wind components throughout the troposphere. Figure 4 shows there is a consistent and significant RMSE reduction of the vector wind for the $1 \mathrm{~d}$ forecast with resolution. The impact of resolution - quantified here by the difference in RMSE between the 80kmEXP and 9kmEXP simulations - is largest near the surface at 850 and $1000 \mathrm{hPa}$, with a RMSE reduction ranging between 0.2 and $0.6 \mathrm{~m} \mathrm{~s}^{-1}$. This is equivalent to a reduction in RMSE of around $15 \%$ near the surface. In the middle and upper troposphere ( 500 and $200 \mathrm{hPa}$ ) there is a consistent but smaller RMSE reduction, ranging between 0.1 and $0.2 \mathrm{~m} \mathrm{~s}^{-1}$.

The RMSE reduction extends throughout the $10 \mathrm{~d}$ forecast for the two components of the wind between 1000 and $850 \mathrm{hPa}$ with values around $0.4 \mathrm{~m} \mathrm{~s}^{-1}$, and it is consistent in both the Northern and Southern Hemisphere and the tropics (not shown). The results are also in agreement with the RMSE with respect to $10 \mathrm{~m}$ wind speed from SYNOP observations, with a mean RMSE reduction over the global domain of $0.34 \mathrm{~m} \mathrm{~s}^{-1}$. The reduction of the mean error is smaller than the RMSE $\left(<0.2 \mathrm{~m} \mathrm{~s}^{-1}\right)$ throughout the troposphere, which means the largest component of the wind error is random.

\subsection{Impact of horizontal resolution on $\mathrm{CO}_{2}$ diurnal and synoptic variability}

The sensitivity of the model skill at hourly and daily timescales to the horizontal resolution of the model is as- sessed with the error of the $\mathrm{CO}_{2}$ simulations with respect to hourly mean observations. The change in the RMSE with horizontal resolution based on the surface $\mathrm{CO}_{2}$ and $\mathrm{XCO}_{2}$ observations (see Sect. 2.1) is shown in Figs. 5 to 7.

At the surface there is an overall substantial reduction of RMSE between 80 and $9 \mathrm{~km}$ (i.e. between 1.8 and $3.5 \mathrm{ppm}$ for hourly data) which is clearly not linear (Fig. 5a and b). The RMSE difference between the 80kmEXP and 40kmEXP simulations or the $40 \mathrm{kmEXP}$ and $25 \mathrm{kmEXP}$ simulations is not as large as the difference between the higherresolution simulations (e.g. the $25 \mathrm{kmEXP}$ and $16 \mathrm{kmEXP}$ or the $16 \mathrm{kmEXP}$ and $9 \mathrm{kmEXP}$ simulations). This is particularly pronounced for the daily maximum $\mathrm{CO}_{2}$ occurring usually at night-time, which is generally controlled by local fluxes and small-scale transport of tracers, and therefore it is more sensitive to resolution. The daily maximum values are generally much better captured at $9 \mathrm{~km}$ resolution compared to $80 \mathrm{~km}$, with a reduction in the RMSE of around $2.5 \mathrm{ppm}$ in January and $6 \mathrm{ppm}$ in July. Indeed, there are large differences between the RMSE of the daily maximum and minimum $\mathrm{CO}_{2}$ values. As expected, daily minimum values that emerge during daytime have a smaller RMSE. This is because during daytime the minimum $\mathrm{CO}_{2}$ values are influenced by the larger-scale fluxes and tracer transport which are less sensitive to high resolution. The reduction in RMSE of the daily minimum $\mathrm{CO}_{2}$ is therefore smaller than for the daily maximum, but it is still considerable, with an RMSE decrease of around $0.75 \mathrm{ppm}$ from 80 to $9 \mathrm{~km}$ resolutions in both January and July. These differences reflect the ability of the model to represent the diurnal cycle. The $9 \mathrm{kmEXP}$ simulation clearly shows a general improvement in the $\mathrm{CO}_{2}$ diurnal cycle near the surface, with smaller differences in the RMSE of the two daily extremes. The largest RMSE reduction comes from mountain sites (over $1000 \mathrm{~m}$ a.m.s.l.), ranging between 6 and 10 ppm for hourly $\mathrm{CO}_{2}$ (Fig. 6a and b), compared to the lowland sites, which can see improvements between 0.5 and 2 ppm for hourly $\mathrm{CO}_{2}$ RMSE near the surface (Fig. 6c and d).

In general there is also a notable reduction in the spread of the RMSE at the different sites with resolution, as shown by the $\sigma$ RMSE values below the panels in Figs. 5 and 6. This implies that the spatial gradients between stations are better represented at higher resolutions. The global mean correlation coefficient also increases with resolution from 0.47 to 0.56 in January and 0.51 to 0.59 in July for the hourly $\mathrm{CO}_{2}$, with consistently higher correlations for the daily mean, minimum and maximum $\mathrm{CO}_{2}$ at higher resolution.

As expected, the sensitivity to the strategy of sampling the model level at observing stations is generally small over lowlands but large over mountains, particularly at low resolution (Fig. S2). At mountain sites, the model level at the real station height above mean sea level is predominantly in the free troposphere, and therefore it has a small sensitivity to the local fluxes and flow, whereas taking the model level with respect to the model ground generally exhibits larger errors 

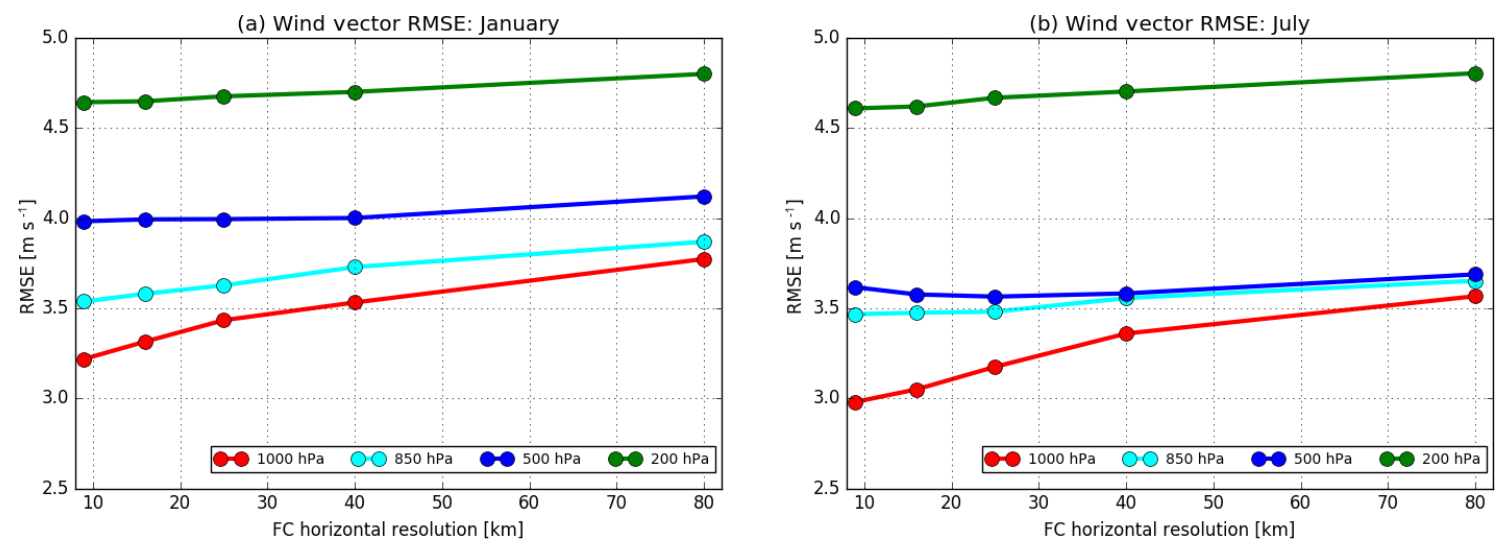

Figure 4. Mean RMSE of vector wind $\left(\mathrm{m} \mathrm{s}^{-1}\right)$ at different model resolutions in (a) January and in (b) July for around 400 radiosonde stations over the globe. Different colours represent different pressure levels (see legend). All the model simulations are based on the standard $1 \mathrm{~d}$ forecast configuration shown in Fig. 3. Note that the number of data at the $1000 \mathrm{hPa}$ level might be slightly smaller than at the other pressure levels, as the observations at $1000 \mathrm{hPa}$ are not available when the surface pressure is lower than $1000 \mathrm{hPa}$.
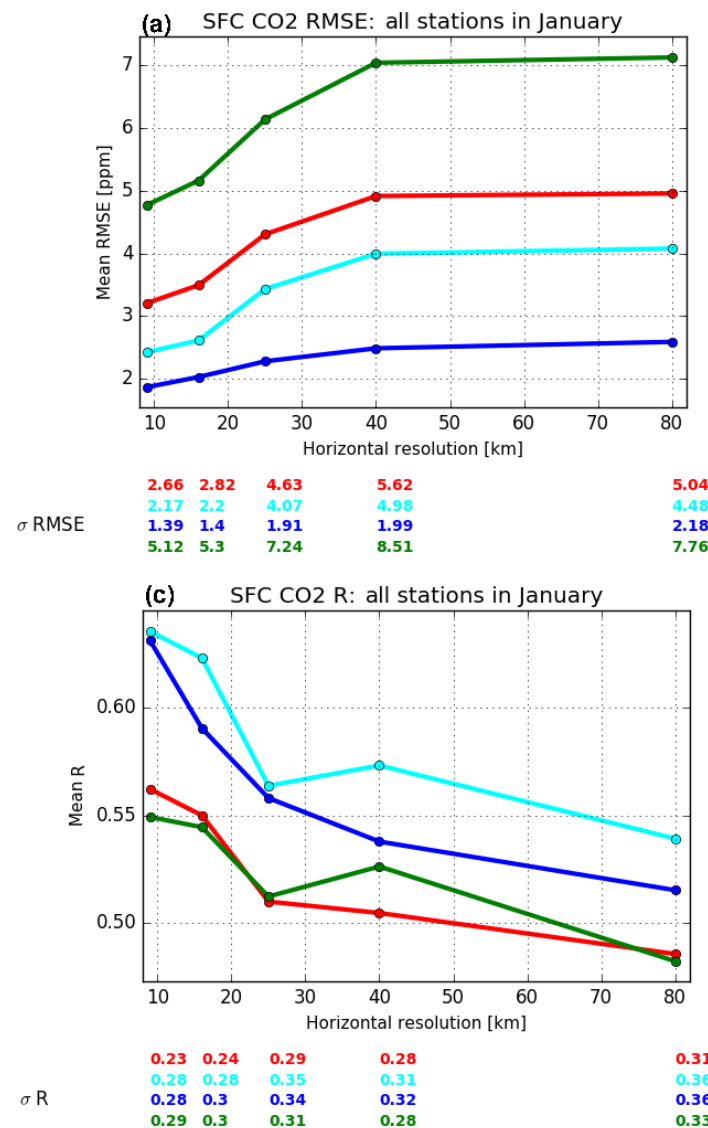

(b) SFC CO2 RMSE: all stations in July
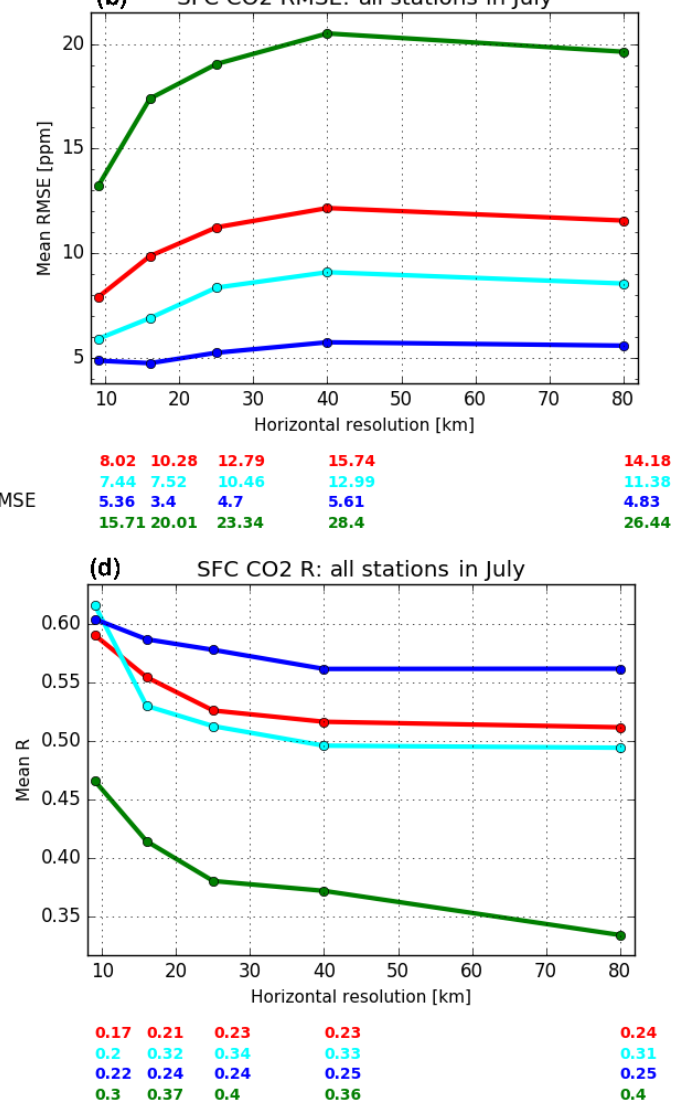

$\leftrightarrow$ SFC hourly $\circ \circ$ SFC daily mean $\leftrightarrow$ SFC daily min $\leftrightarrow$ SFC daily max

Figure 5. Mean RMSE of near-surface $\mathrm{CO}_{2}(\mathrm{ppm})(\mathbf{a}, \mathbf{b})$ and Pearson's correlation coefficient $R$ (c, d) at different model resolutions in January (a, c) and July (b, d) for all 51 stations (see Table A1). The standard deviation of the plotted variable from each station is shown by the numbers below the horizontal resolution for each temporal resolution (hourly, daily mean, daily min and daily max). All the model simulations are based on the $1 \mathrm{~d}$ forecast. Note that different scales are used in each panel. 


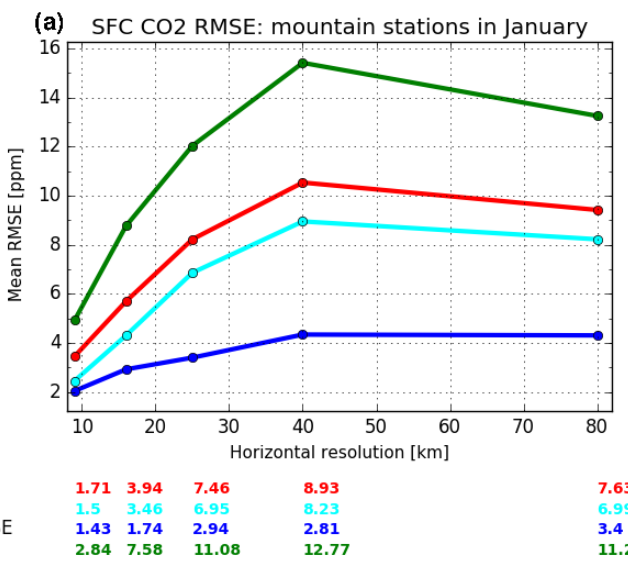

(c) SFC CO2 RMSE: lowland stations in January

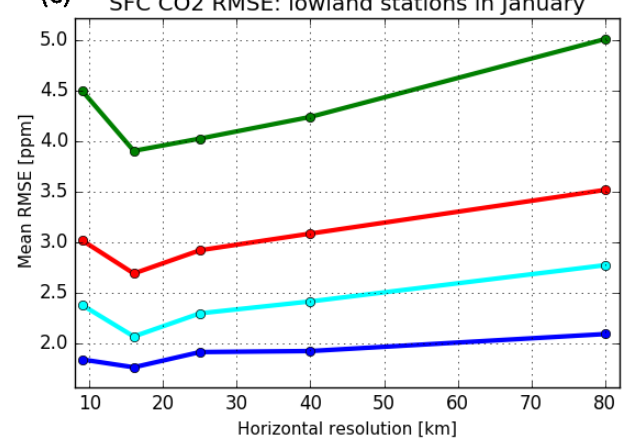

$\sigma$ RMSE

$$
\begin{array}{lllll}
2.77 & 1.71 & 1.96 & 2.17 & 2.83 \\
2.36 & 1.3 & 1.59 & 1.64 & 2.28 \\
\mathbf{1 . 4 2} & \mathbf{1 . 2} & \mathbf{1 . 3 3} & \mathbf{1 . 2 5} & \mathbf{1 . 3 3} \\
\mathbf{5 . 4 4} & \mathbf{3 . 7} & \mathbf{3 . 7 9} & \mathbf{4 . 0 3} & \mathbf{4 . 8 9}
\end{array}
$$

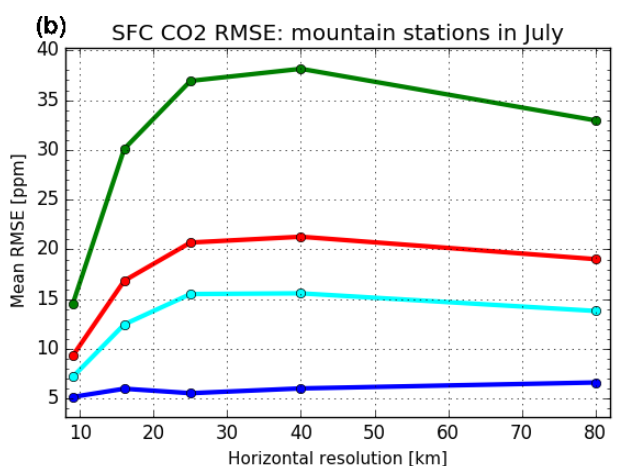

$\sigma$ RMSE

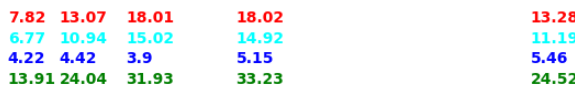

(d) SFC CO2 RMSE: lowland stations in July
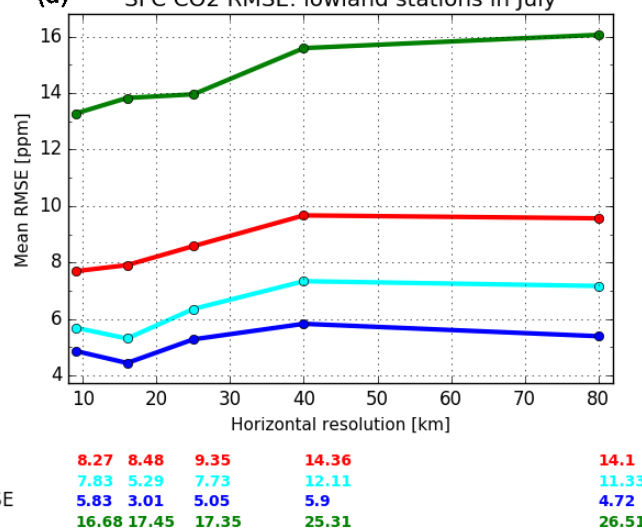

13.28
11.19

24.52

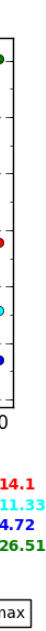

Figure 6. Mean RMSE of near-surface $\mathrm{CO}_{2}(\mathrm{ppm})$ at different model resolutions in January (a, c) and July (b, d) for (a, b) 37 lowland stations (below $1000 \mathrm{~m}$ a.m.s.l.) and (c, d) 12 mountain stations (1000 m a.m.s.l., excluding bao and spo, as listed in Table A1). The standard deviation of the plotted variable from each station is shown by the numbers below the horizontal resolution for each temporal resolution (hourly, daily mean, daily min and daily max). All the model simulations are based on the $1 \mathrm{~d}$ forecast. Note that different scales are used in each panel.

associated with local influences in the boundary layer. The difference between the two sampling strategies in the RMSE and correlation coefficients becomes smaller at high resolution (Fig. S3). This reflects an improvement in the capability of the model to represent the flow and fluxes around complex topography at higher horizontal resolution.

The $\mathrm{XCO}_{2}$ RMSE at the TCCON sites during daytime also displays a general decrease with resolution (Fig. 7), with differences of the order of $0.1 \mathrm{ppm}$ from 80 to $9 \mathrm{~km}$ resolutions and increases in the correlation coefficients $(r)$ of up to 0.05. In boreal summer, the $\mathrm{XCO}_{2}$ daily minimum has the largest/smallest RMSE/ $r$ because it reflects the uncertainty associated with modelled photosynthesis and negative $\mathrm{XCO}_{2}$ anomalies, whereas in boreal winter, the $\mathrm{XCO}_{2}$ daily maximum has the largest RMSE because ecosystem respiration associated with positive $\mathrm{XCO}_{2}$ anomalies is the dominant process at most TCCON sites. It is likely that the larger footprint of $\mathrm{XCO}_{2}$ (Belikov et al., 2017) at most TCCON sta- tions - associated with its sensitivity to large-scale flux patterns - (Keppel-Aleks et al., 2011, 2012) is causing most TCCON sites to be less sensitive to horizontal resolution. However, there is a large variation in RMSE between sites (see $\sigma$ RMSE in Figs. 7 and S9), which is reduced at high resolution. In particular, the TCCON site at Pasadena (California, USA), located near the anthropogenic emission hotspot of the megacity of Los Angeles, stands out (Fig. S9). The improvement associated with high resolution at Pasadena is indeed remarkable in January (i.e. approximately 2 ppm RMSE reduction). A more detailed study for Pasadena is provided in Sect. 3.5.

The change of RMSE with resolution is partly associated with the improvement in the transport and also the representation of the local fluxes at higher resolutions. Figure 8 shows that when the fluxes are switched off during the $1 \mathrm{~d}$ forecast, there is still an improvement with resolution at most sites, but the magnitude of the error reduction is smaller (see sym- 

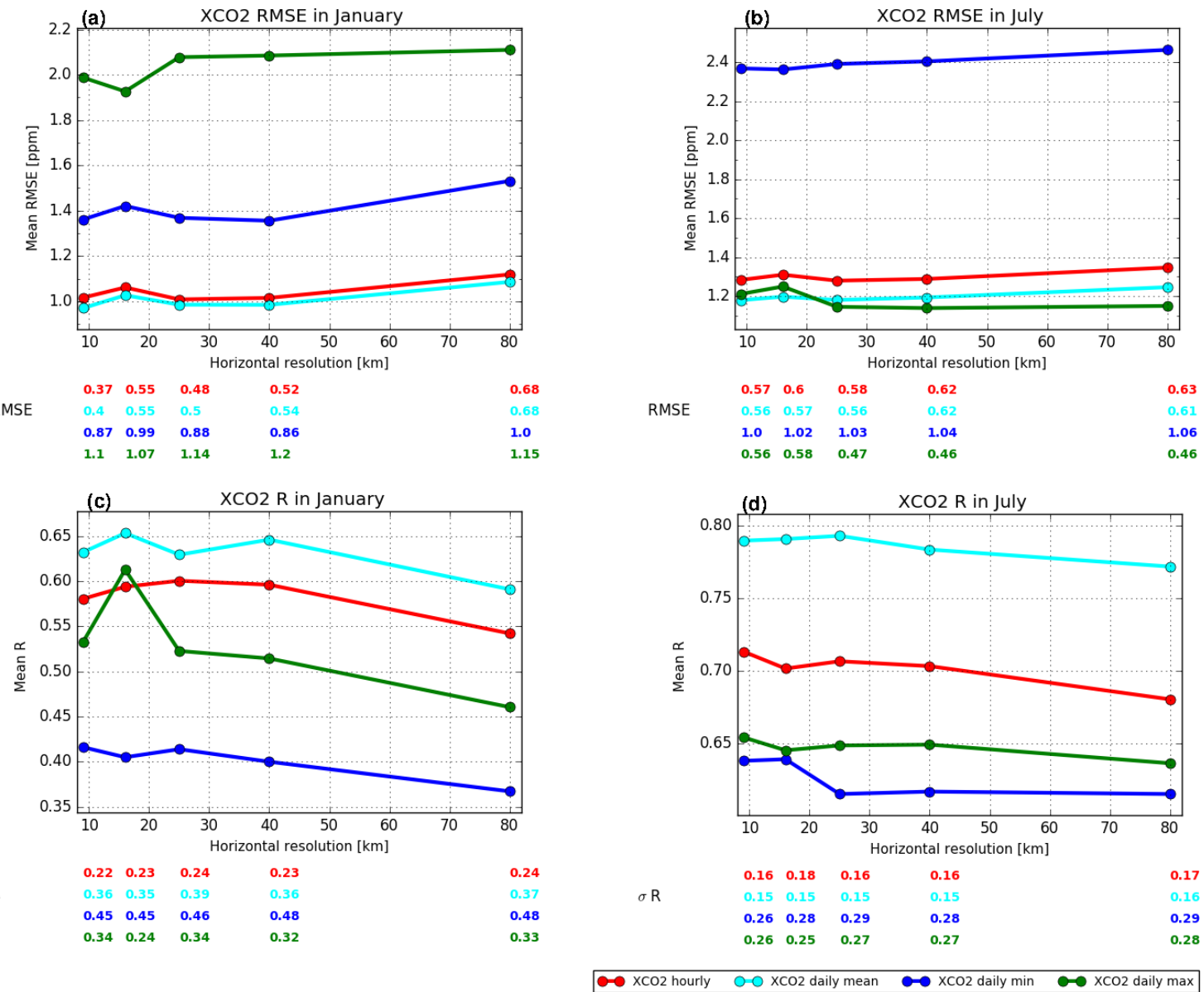

Figure 7. Mean RMSE of $\mathrm{XCO}_{2}$ (ppm) and Pearson's correlation coefficient $R$ with respect to observations from 18 TCCON stations (see Table A3) at different model resolutions in (a) January and (b) July. The standard deviation of the plotted variable from each station is shown by the numbers below the horizontal resolution for each temporal resolution (hourly, daily mean, daily min and daily max). All the model simulations are based on the $1 \mathrm{~d}$ forecast. Note that different scales are used in each panel.

bols to the right of the dashed line). This is very clear for a large number of mountain sites and TCCON sites affected by anthropogenic emissions such as Pasadena (USA) in January and Saga (Japan) in July. However, there are also some sites and months in which the impact of resolution is better without fluxes than with fluxes (e.g. Pasadena in July). This would indicate that in this case the errors in the fluxes are the main cause of the deterioration in RMSE with resolution.

The overall global error statistics of the $9 \mathrm{kmEXP}$ and $80 \mathrm{kmEXP}$ simulations including the systematic (or bias) error and the standard (or random) error are shown in Table 3. The reduction in RMSE at $9 \mathrm{~km}$ is associated with a decrease in the magnitude of the $\mathrm{CO}_{2}$ biases on average of 1.5 to $2 \mathrm{ppm}$ near the surface and up to $0.2 \mathrm{ppm}$ for $\mathrm{XCO}_{2}$ and a general reduction in the $\mathrm{CO}_{2}$ random error of 1 to $1.5 \mathrm{ppm}$ near the surface and $0.1 \mathrm{ppm}$ for $\mathrm{XCO}_{2}$ (Figs. S4 and S5). The biases depend largely on the bias of the $\mathrm{CO}_{2}$ initial conditions, as well as the biases of the fluxes and tracer transport. What is important in this sensitivity study is that the standard deviation of the bias at each station - i.e. the inter-station bias - is reduced at $9 \mathrm{~km}$ with respect to $80 \mathrm{~km}$, as shown by the shaded area in Figs. S4 and S5. The largest decrease in the inter-station bias between 80kmEXP and 9kmEXP simulations occurs in January, when it is almost halved near the surface. The errors at the individual observing stations are listed in Tables S1, S2, S3 and S4.

\subsection{Impact of horizontal resolution on $\mathrm{CO}_{2}$ forecast error growth}

In $10 \mathrm{~d}$ the global mean RMSE of $\mathrm{CO}_{2}$ forecast at the in situ surface stations grows by around $1.4 \mathrm{ppm}$ in January and around $1 \mathrm{ppm}$ in July (Fig. 9). It is worth noting that this error growth is smaller in magnitude than the impact of increasing horizontal resolution from 80 to $9 \mathrm{~km}$. Namely, the $10 \mathrm{~d}$ forecast at $9 \mathrm{~km}$ is better than the $1 \mathrm{~d}$ forecast at $80 \mathrm{~km}$ near the surface. At the TCCON sites the $\mathrm{XCO}_{2}$ RMSE grows on average between 0.2 and $0.5 \mathrm{ppm}$ in $10 \mathrm{~d}$ (Fig. 10). The forecast RMSE growth for near-surface $\mathrm{CO}_{2}$ and $\mathrm{XCO}_{2}$ does 

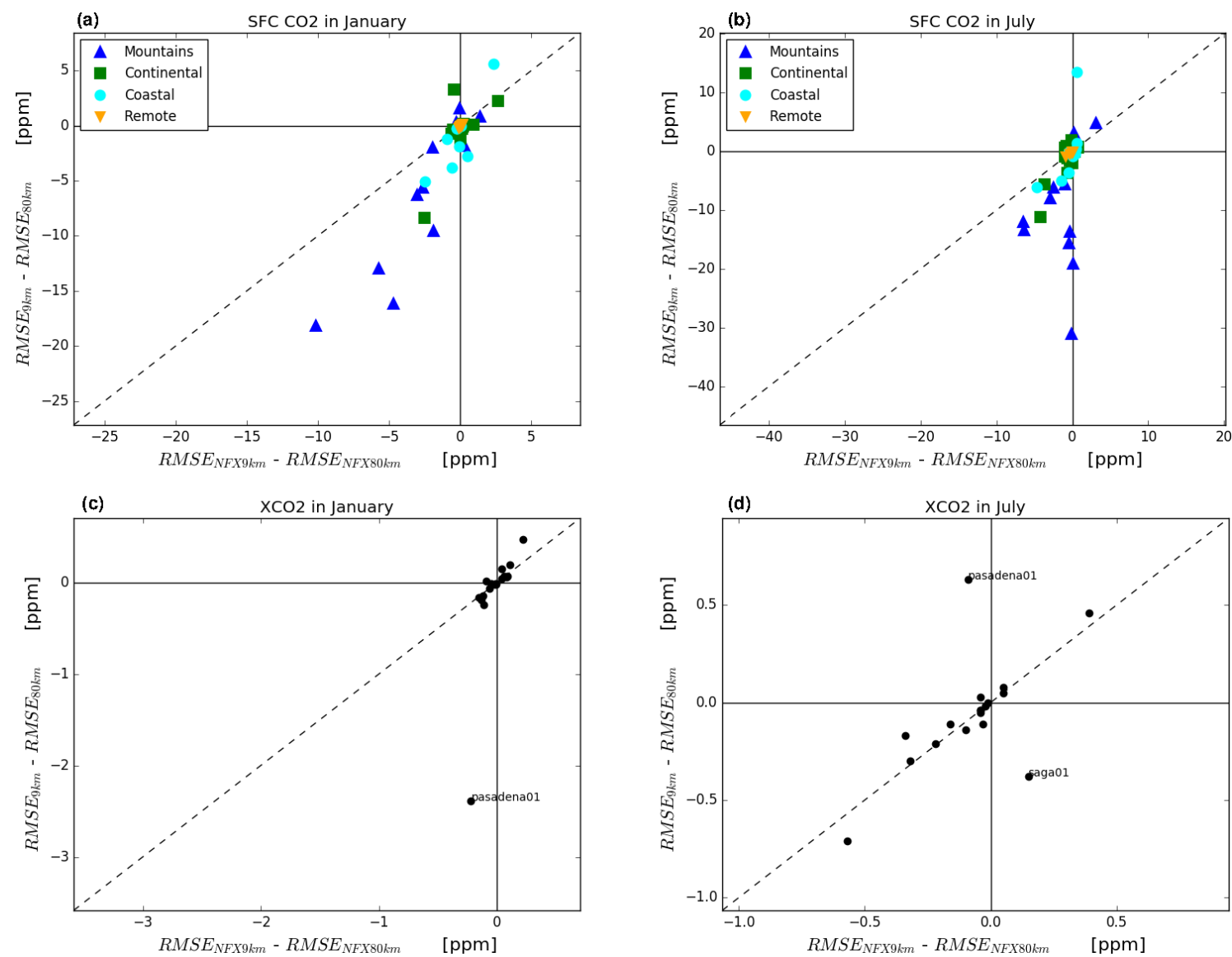

Figure 8. Sensitivity of horizontal resolution impact to surface $\mathrm{CO}_{2}$ fluxes at (a, b) surface stations and (c, d) TCCON stations in January and July, as shown by the difference in RMSE between different $\mathrm{CO}_{2}$ tracers, i.e. the standard tracer $\left(\mathrm{RMSE}_{9 \mathrm{~km}}-\mathrm{RMSE}_{80 \mathrm{~km}}\right)$ and the $\mathrm{CO}_{2}$ tracer with just transport (RMSE $\mathrm{NFX}_{9 \mathrm{~km}}-\mathrm{RMSE}_{\mathrm{NFX} 80 \mathrm{~km}}$ ) in the $y$ axis and $x$ axis respectively. The symbols that are close to the dashed line correspond to stations that have a small sensitivity to local fluxes, while at the stations associated with symbols that are located above/below the dashed line there is a negative/positive contribution of the local fluxes at high resolution. The further from the dashed line, the larger the contribution of the local fluxes. The stations located along the $y$ axis are mainly impacted by local fluxes. The surface stations in (a, b) are depicted with different symbols depending on whether they are classified as mountain, continental, coastal or remote (see Table A1), while TCCON stations that are strongly influenced by fluxes are labelled with station names. Note that different scales are used in each panel.

not appear to be linear, with a slow growth until day 4 and a faster increase from day 5 onwards. The $\mathrm{CO}_{2}$ RMSE growth at $80 \mathrm{~km}$ is slightly faster than at $9 \mathrm{~km}$. In summary, the gain in skill from horizontal resolution is maintained throughout the $10 \mathrm{~d}$ forecast. Thus, the results suggests that the horizontal resolution has a small but positive impact on the shortand medium-range forecast skill for $\mathrm{CO}_{2}$ and $\mathrm{XCO}_{2}$.

As expected, the RMSE in July is largest because of the high uncertainty associated with the modelled biogenic fluxes at synoptic scales which influence the variability at continental sites (Agustí-Panareda et al., 2014). There is also a larger uncertainty in the meteorology driving the tracer transport during summer compared to winter (Haiden et al., 2017). The fact that the forecast RMSE for day 1 is larger than for day 2 in July is associated with a sporadic overestimation of daily maximum $\mathrm{CO}_{2}$ peaks at sites influenced by strong local fluxes. There are several potential causes of the overestimation (e.g. biogenic fluxes responding to rapid adjustments in meteorology after analysis re-initialisation at 00:00 UTC or issues with the tracer transport associated with the short spin-up period), but these are beyond the scope of this study.

The near-surface $\mathrm{CO}_{2}$ RMSE increase during the forecast appears to come mostly from an increase in random error in January and from both mean and random error in July (Fig. S4), whereas for $\mathrm{XCO}_{2}$, both mean and random errors contribute equally to the forecast RMSE growth in January and July (Fig. S5). This is probably linked to the distribution of the stations, as most in situ stations are located in the Northern Hemisphere, whereas TCCON stations are more equally distributed in both hemispheres, and thus, the mean error at all stations does not show differences between summer and winter conditions. 
Table 3. Surface $\mathrm{CO}_{2}$ and $\mathrm{XCO}_{2}$ mean statistics for bias, STDE and RMSE of all stations and the standard deviation of inter-station statistics (in brackets and bold font) from the highest- and lowest-resolution simulations, i.e. $9 \mathrm{kmEXP}$ and $80 \mathrm{kmEXP}$ respectively. All the $\mathrm{SFC} \mathrm{CO}_{2}$ stations used in January and July are listed in Tables S1 and S2; the TCCON stations used in the $\mathrm{XCO}_{2}$ statistics are listed in Tables $\mathrm{S} 3$ and S4.

\begin{tabular}{|c|c|c|c|c|c|c|c|c|}
\hline \multirow[t]{2}{*}{ Data } & \multirow[t]{2}{*}{ Period } & \multirow{2}{*}{$\begin{array}{l}\text { Temporal } \\
\text { resolution }\end{array}$} & \multicolumn{2}{|c|}{ Bias } & \multicolumn{2}{|c|}{ STDE } & \multicolumn{2}{|c|}{ RMSE } \\
\hline & & & $9 \mathrm{kmEXP}$ & 80kmEXP & $9 \mathrm{kmEXP}$ & 80kmEXP & 9kmEXP & 80kmEXP \\
\hline \multirow{4}{*}{$\mathrm{SFC} \mathrm{CO}_{2}$} & \multirow{4}{*}{ January } & Hourly mean & $-0.09(\mathbf{2 . 2 5})$ & $1.73(4.70)$ & $2.70(\mathbf{2 . 2 5})$ & $3.78(\mathbf{3 . 2 8})$ & $3.21(\mathbf{2 . 6 6})$ & $4.96(\mathbf{5 . 0 4})$ \\
\hline & & Daily mean & $-0.06(\mathbf{2 . 3 5})$ & $1.76(4.71)$ & $1.76(\mathbf{1 . 4 3})$ & $2.59(2.21$ & $2.43(\mathbf{2 . 1 7})$ & $4.08(\mathbf{4 . 4 8})$ \\
\hline & & Daily min & $-0.30(\mathbf{1 . 4 8})$ & $0.62(\mathbf{2 . 4 4})$ & $1.41(\mathbf{1 . 0 9})$ & $1.82(\mathbf{1 . 3 8})$ & 1.87 (1.39) & $2.59(\mathbf{2 . 1 8})$ \\
\hline & & Daily max & $0.02(\mathbf{4 . 4 3})$ & $2.66(7.82)$ & $3.68(4.00)$ & $4.73(4.56)$ & 4.77 (5.12) & $7.12(7.76)$ \\
\hline \multirow{4}{*}{$\mathrm{SFC} \mathrm{CO}_{2}$} & \multirow{4}{*}{ July } & Hourly mean & $0.96(\mathbf{5 . 7 6})$ & $2.67(\mathbf{9 . 6 4 )}$ & $6.70(6.94)$ & 9.64 (11.93) & 7.90 (8.02) & $11.56(\mathbf{1 4 . 1 8})$ \\
\hline & & Daily mean & $1.14(\mathbf{6 . 5 5})$ & $2.84(\mathbf{9 . 8 0})$ & $4.08(\mathbf{5 . 4 6})$ & $5.52(\mathbf{8 . 3 0})$ & $5.91(7.44)$ & 8.55 (11.38) \\
\hline & & Daily min & $1.48(4.17)$ & $0.86(\mathbf{4 . 8 2})$ & $3.70(\mathbf{4 . 4 0})$ & $4.11(3.74)$ & 4.87 (5.36) & $5.59(\mathbf{4 . 8 3})$ \\
\hline & & Daily max & $-0.44(\mathbf{1 4 . 0 9})$ & $5.07(\mathbf{2 3 . 0 5})$ & 9.10 (11.91) & $12.20(\mathbf{1 9 . 5 7})$ & $13.22(\mathbf{1 5 . 7 1})$ & $19.63(\mathbf{2 6 . 4 4 )}$ \\
\hline \multirow{4}{*}{$\mathrm{XCO}_{2}$} & \multirow{4}{*}{ January } & Hourly mean & $-0.49(\mathbf{0 . 7 4})$ & $-0.38(\mathbf{0 . 9 2})$ & $0.58(\mathbf{0 . 2 6})$ & $0.69(\mathbf{0 . 5 4})$ & $1.02(\mathbf{0 . 3 7})$ & $1.12(\mathbf{0 . 6 8})$ \\
\hline & & Daily mean & $-0.51(\mathbf{0 . 7 7})$ & $-0.38(\mathbf{0 . 9 9})$ & $0.47(\mathbf{0 . 2 3})$ & $0.58(\mathbf{0 . 4 8})$ & $0.97(\mathbf{0 . 4 0})$ & $1.09(\mathbf{0 . 6 8})$ \\
\hline & & Daily min & 0.60 (1.09) & 0.75 (1.18) & $0.92(\mathbf{0 . 5 1})$ & $1.03(\mathbf{0 . 6 0})$ & $1.36(\mathbf{0 . 8 7})$ & $1.53(\mathbf{1 . 0})$ \\
\hline & & Daily max & $-1.60(\mathbf{1 . 0 1})$ & $-1.49(\mathbf{1 . 2 3})$ & $1.00(\mathbf{0 . 7 7})$ & $1.13(\mathbf{0 . 9 1})$ & 1.99 (1.1) & $2.11(\mathbf{1 . 1 5})$ \\
\hline \multirow{4}{*}{$\mathrm{XCO}_{2}$} & \multirow{4}{*}{ July } & Hourly mean & $1.01(\mathbf{0 . 7 4})$ & $1.04(\mathbf{0 . 9 2})$ & $0.71(\mathbf{0 . 3 2})$ & $0.74(\mathbf{0 . 2 9})$ & $1.28(\mathbf{0 . 5 7})$ & $1.35(\mathbf{0 . 6 3})$ \\
\hline & & Daily mean & 0.99 (0.77) & $1.03(\mathbf{0 . 9 9})$ & $0.56(\mathbf{0 . 2 8})$ & $0.59(\mathbf{0 . 2 7})$ & $1.18(\mathbf{0 . 5 6})$ & $1.25(\mathbf{0 . 6 1})$ \\
\hline & & Daily min & 2.09 (1.09) & 2.18 (1.18) & $1.05(\mathbf{0 . 6 7})$ & $1.07(\mathbf{0 . 6 9 )}$ & 2.37 (1.00) & $2.46(\mathbf{1 . 0 6})$ \\
\hline & & Daily max & $-0.01(\mathbf{1 . 0 1})$ & $-0.07(\mathbf{1 . 2 3})$ & $0.92(\mathbf{0 . 4 8})$ & $0.87(\mathbf{0 . 4 5})$ & $1.21(\mathbf{0 . 5 6})$ & $1.15(\mathbf{0 . 4 6})$ \\
\hline
\end{tabular}
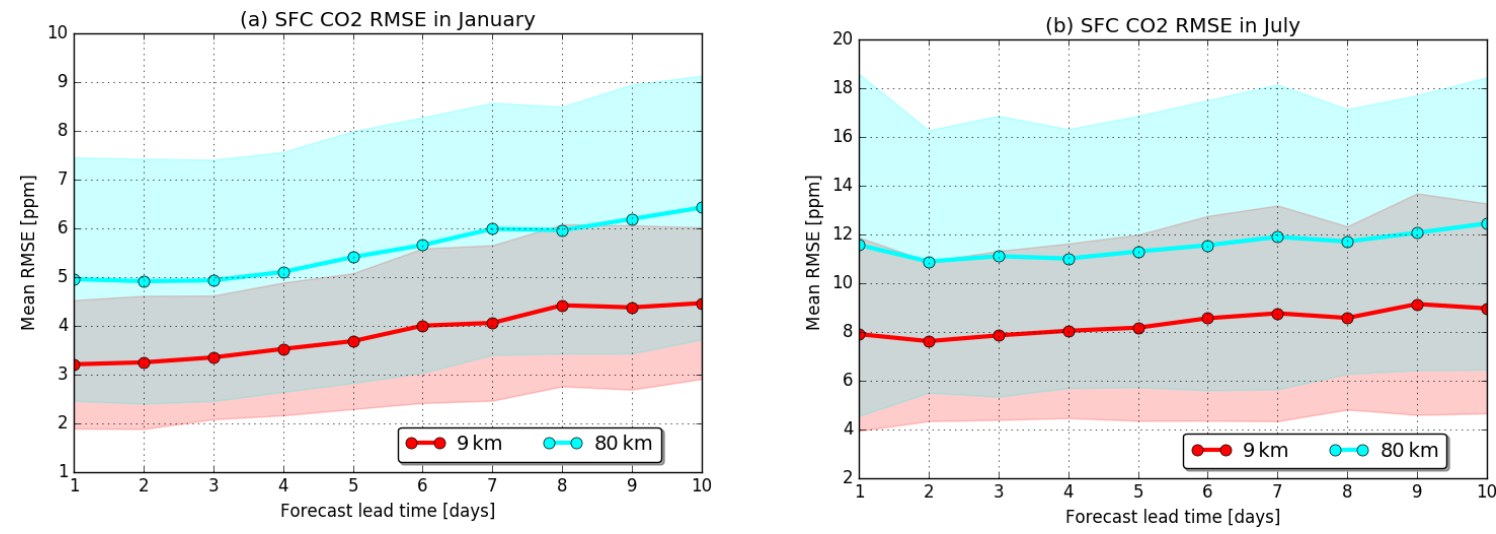

Figure 9. Mean RMSE of near-surface $\mathrm{CO}_{2}(\mathrm{ppm})$ at different forecast lead times for the 9kmEXP (red) and 80kmEXP (blue) in (a) January and (b) July. The errors are computed with respect to hourly continuous in situ surface measurements from 51 stations (see Table A1). The error standard deviation between the different stations is shown with the shaded area: red for 9kmEXP, blue for $80 \mathrm{kmEXP}$ and grey for overlap. Note that different scales are used in each panel.

\subsection{Impact of horizontal resolution on $\mathrm{CO}_{2}$ small-scale variability}

The sensitivity of the RMSE to resolution is generally associated with regions that are affected by small-scale variability that cannot be properly represented by typical global tracer transport models (Law et al., 2008; Patra et al., 2008). Figure 11 shows that the mean small-scale variability, given by the standard deviation within $1^{\circ} \times 1^{\circ}$ grid box, can be as large as $10 \mathrm{ppm}$ near emission hotspots at the surface during daytime. The representation of the $\mathrm{CO}_{2}$ small-scale vari- ability at the surface in the $9 \mathrm{kmEXP}$ compared to the $80 \mathrm{~km}$ EXP is also illustrated in Fig. S6. Larger values than $10 \mathrm{ppm}$ can be found over most land areas at night-time (Fig. 12). These values are likely to be underestimated, since we expect horizontal gradients to become steeper as the resolution increases, the point sources associated with anthropogenic activities become stronger at the grid cell scale and part of the sub-grid-scale flow is resolved.

Coastal sites and mountain sites have a typical sub-gridscale variability of around $5 \mathrm{ppm}$ during daytime. This variability varies from January to July, depending on meteoro- 

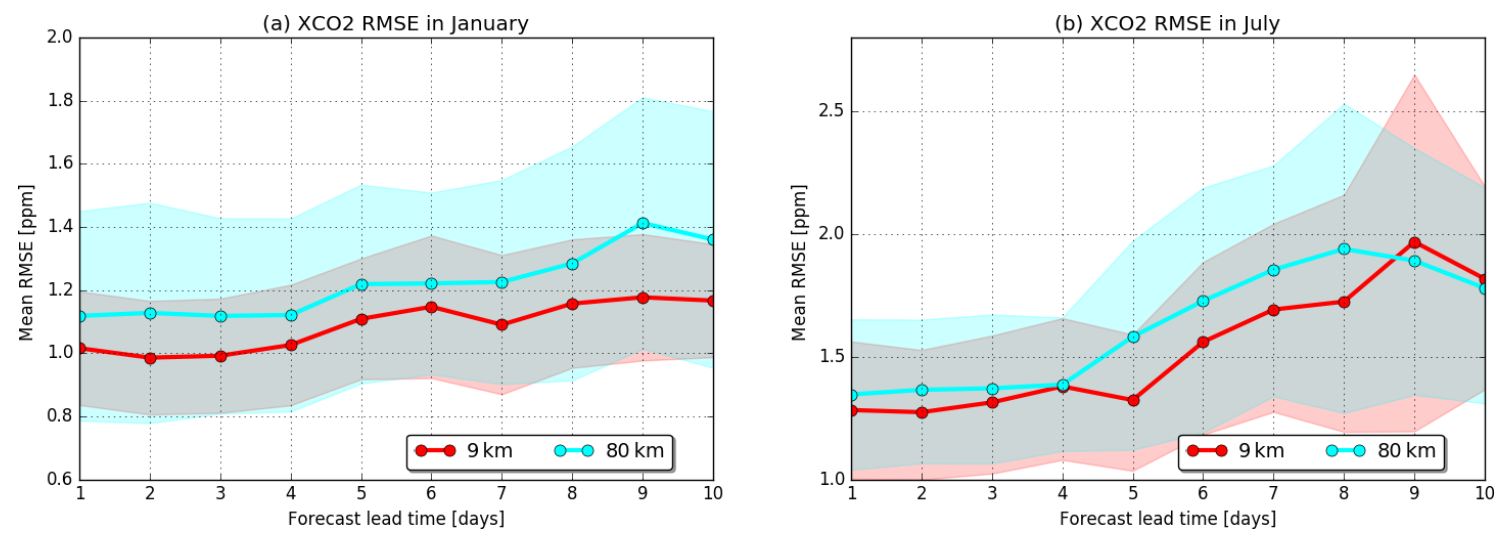

Figure 10. Same as Fig. 9 but for $\mathrm{XCO}_{2}$ (ppm). The errors are computed with respect to hourly TCCON observations from 18 TCCON stations (see Table A3).
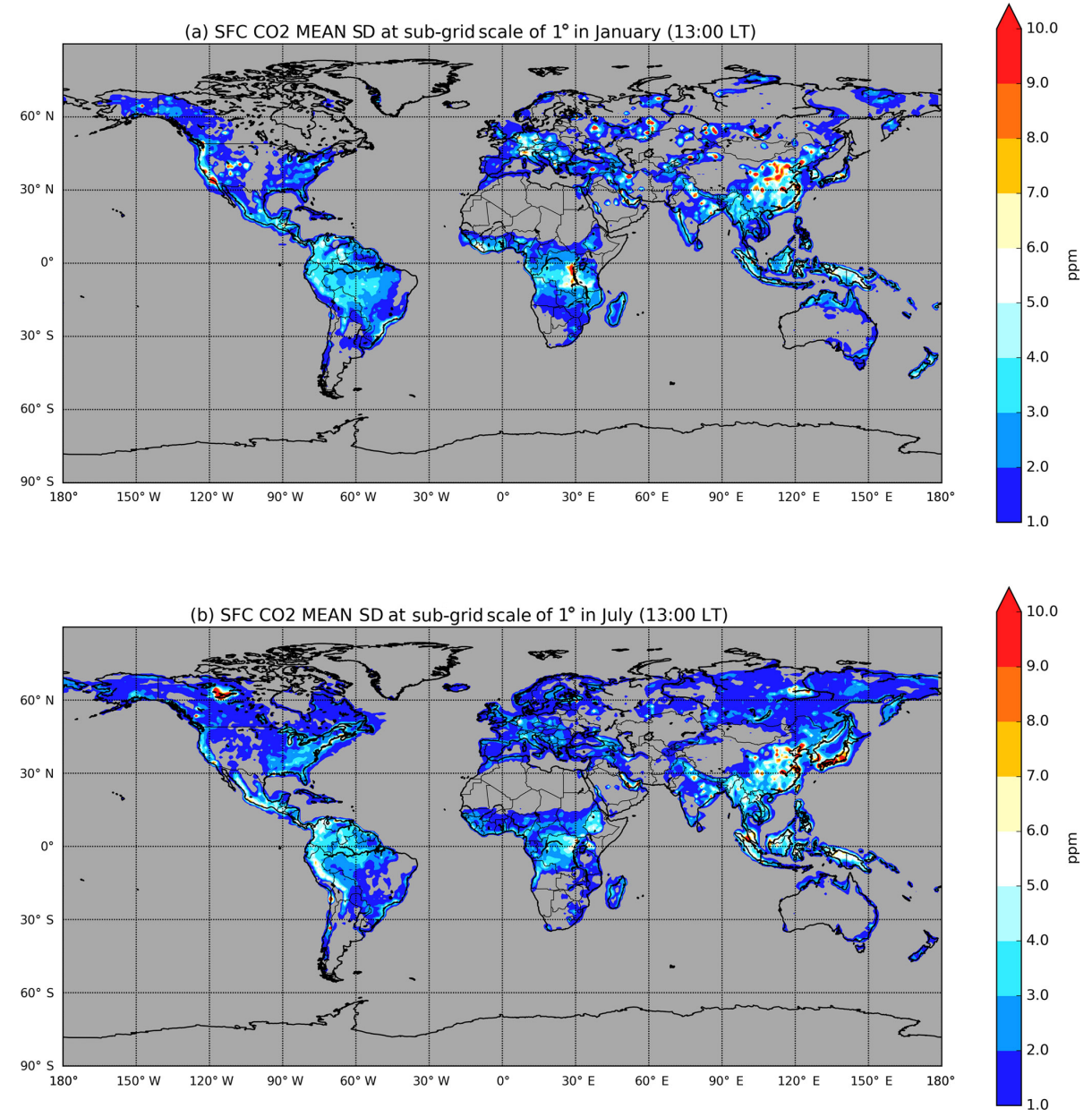

Figure 11. Monthly mean surface $\mathrm{CO}_{2}$ small-scale variability $(\sigma)$ within $1^{\circ} \times 1^{\circ}$ grid boxes (ppm) at 13:00 local time in (a) January and (b) July. Grey shading denotes $\sigma<1.0$. 

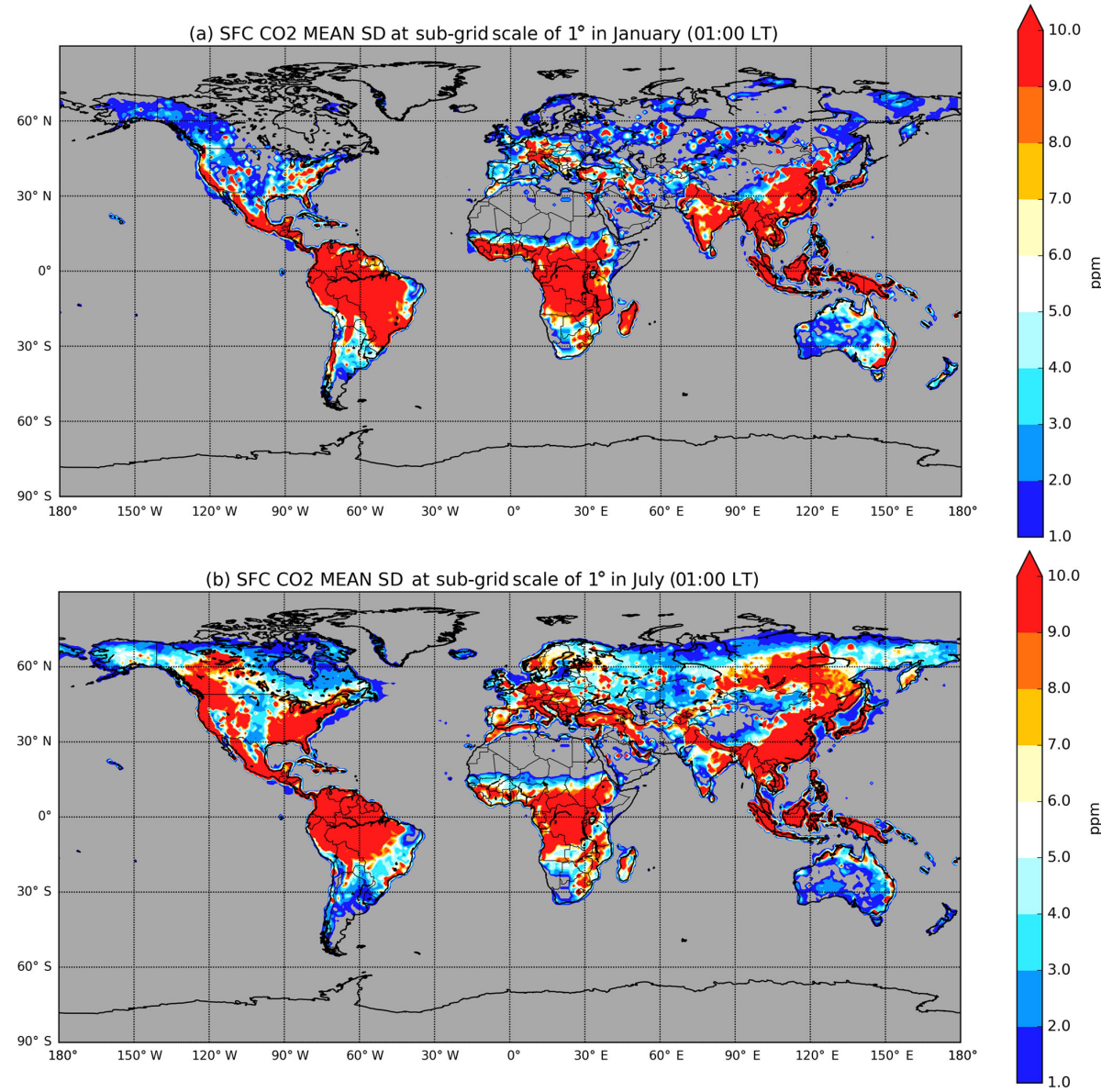

Figure 12. Monthly mean surface $\mathrm{CO}_{2}$ small-scale variability $(\sigma)$ within $1^{\circ} \times 1^{\circ}$ grid boxes (ppm) at 01:00 local time in (a) January and (b) July. Grey shading denotes $\sigma<1.0$.

logical conditions (e.g. stagnant or windy conditions) and the magnitude and sign of fluxes (e.g. biogenic activity shifting northwards in Northern Hemisphere summer). Over land, the patterns of sub-grid-scale variability of surface and total column are consistent (Figs. 11 and 13), as both are subject to surface heterogeneity in terms of topography and fluxes. However, there is a difference in magnitude because the variability of the total column average is much smaller than the variability at the surface.

$\mathrm{XCO}_{2}$ has a maximum standard deviation of $1 \mathrm{ppm}$ near surface flux hotspots and typically less than $0.5 \mathrm{ppm}$ in most regions (Fig. 13), which is consistent with other estimates from regional studies (Corbin et al., 2008; Pillai et al., 2010) (see also Fig. S7 for a visual illustration). The differences in the small-scale $\mathrm{XCO}_{2}$ variability between day and night appear to be small. Interestingly, the small-scale variability of $\mathrm{XCO}_{2}$ is much larger in summer than in winter (both in the Northern and Southern Hemisphere). During the growing season, negative $\mathrm{CO}_{2}$ anomalies associated with plant photosynthesis and positive anomalies associated with ecosystem respiration and anthropogenic emissions combine to create steeper gradients throughout the troposphere - as illustrated in Fig. $1 \mathrm{~b}$ - that contribute to the enhanced sub-grid-scale variability in summer compared to winter. Over the ocean, the small-scale variability of $\mathrm{XCO}_{2}$ ranges between 0.1 and $0.3 \mathrm{ppm}$, with lower values in the winter and higher values in the summer. In the Northern Hemisphere summer, the values over the ocean and over the land are comparable, whereas near the surface, the mean sub-grid-scale variability is an order of magnitude smaller over the ocean than over land. This is because over land the surface fluxes dominate the gradients resulting in the steepest gradients being near the surface, while over the ocean, the transport associated with the weather systems creates steep $\mathrm{CO}_{2}$ gradients in the free troposphere. Therefore, column-averaged $\mathrm{CO}_{2}$ is much more likely to be influenced by sub-grid-scale variability associated with weather systems than by surface $\mathrm{CO}_{2}$ fluxes over the ocean. 

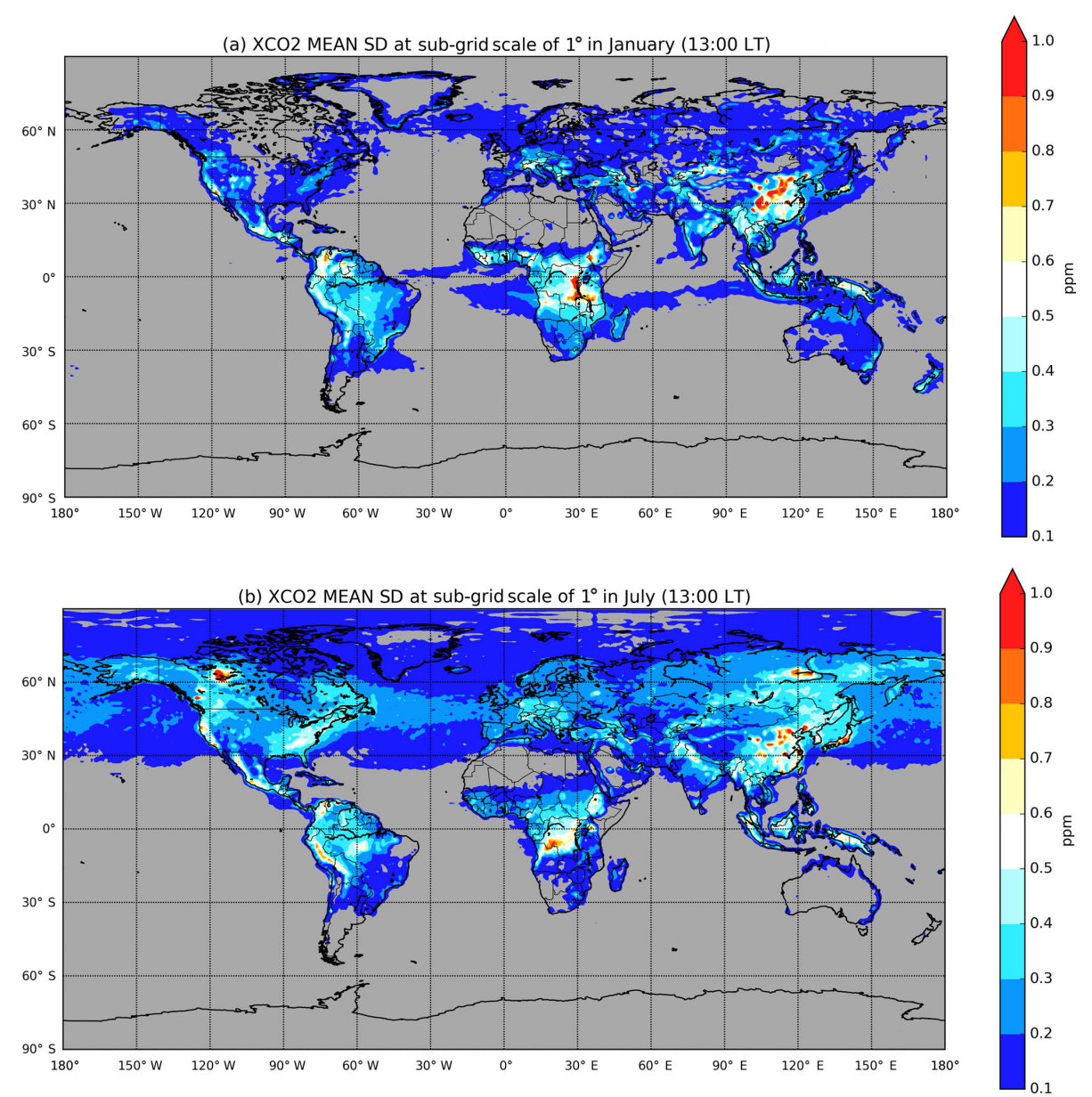

Figure 13. Monthly mean $\mathrm{XCO}_{2}$ small-scale variability $(\sigma)$ within $1^{\circ} \times 1^{\circ}$ grid boxes (ppm) at 13:00 local time in (a) January and (b) July. Grey shading denotes $\sigma<0.1$.

\subsection{Example of horizontal resolution impact at an urban site}

Although the winds, the topography and the spatial heterogeneity of the fluxes are generally better represented at high horizontal resolution, there can still be a deterioration in the RMSE scores at sites where the local influence is strong and the emissions/biogenic fluxes have large errors in the model. In this section we present an example of such a case at the Caltech TCCON site in Pasadena (California, USA; see Table $\mathrm{A} 3$ ) with $\mathrm{XCO}_{2}$ under clear-sky and daylight conditions. The variability of the simulated $\mathrm{XCO}_{2}$ exhibits a substantial improvement with high resolution in winter and an equally considerable deterioration in summer (Fig. 15). Thus, it illustrates some of the challenges associated with urban regions.

Pasadena is located $14 \mathrm{~km}$ north-east of the megacity of Los Angeles (LA) with a large local anthropogenic emission influence (Wunch et al., 2009; Newman et al., 2016). The $\mathrm{XCO}_{2}$ variability in the model is also mainly explained by the local anthropogenic emissions (Figs. S10 and S11) producing very large $\mathrm{CO}_{2}$ enhancements in the planetary bound- ary layer (PBL) (Fig. S12) and therefore in $\mathrm{XCO}_{2}$. The $\mathrm{CO}_{2}$ budget of the anthropogenic emissions used at 9 and $80 \mathrm{~km}$ is the same. However, the instantaneous values of the emissions per square metre are much higher at 9 than at $80 \mathrm{~km}$, representing some of the steep gradients and heterogeneous distribution of fossil fuel emissions within the LA basin, with higher emissions in downtown LA and lower emissions in Pasadena (e.g. Feng et al., 2016). At $80 \mathrm{~km}$, Pasadena and downtown LA are in the same model grid box, which means this gradient cannot be represented. In addition to the influence of anthropogenic emissions, the seasonal variation of the winds is very pronounced in Pasadena, with a large contrast in the origin or air masses between winter and summer (Verhulst et al., 2017).

In winter, air masses originate from various directions: from the prevailing westerly and southerly winds, bringing and accumulating polluted air from the LA megacity, to northerly and easterly flow, characterised by cleaner air with lower $\mathrm{CO}_{2}$ values from the surrounding desert and mountains (Newman et al., 2016). Persistent low wind conditions lead to a large accumulation of $\mathrm{CO}_{2}$ in the LA basin as it 

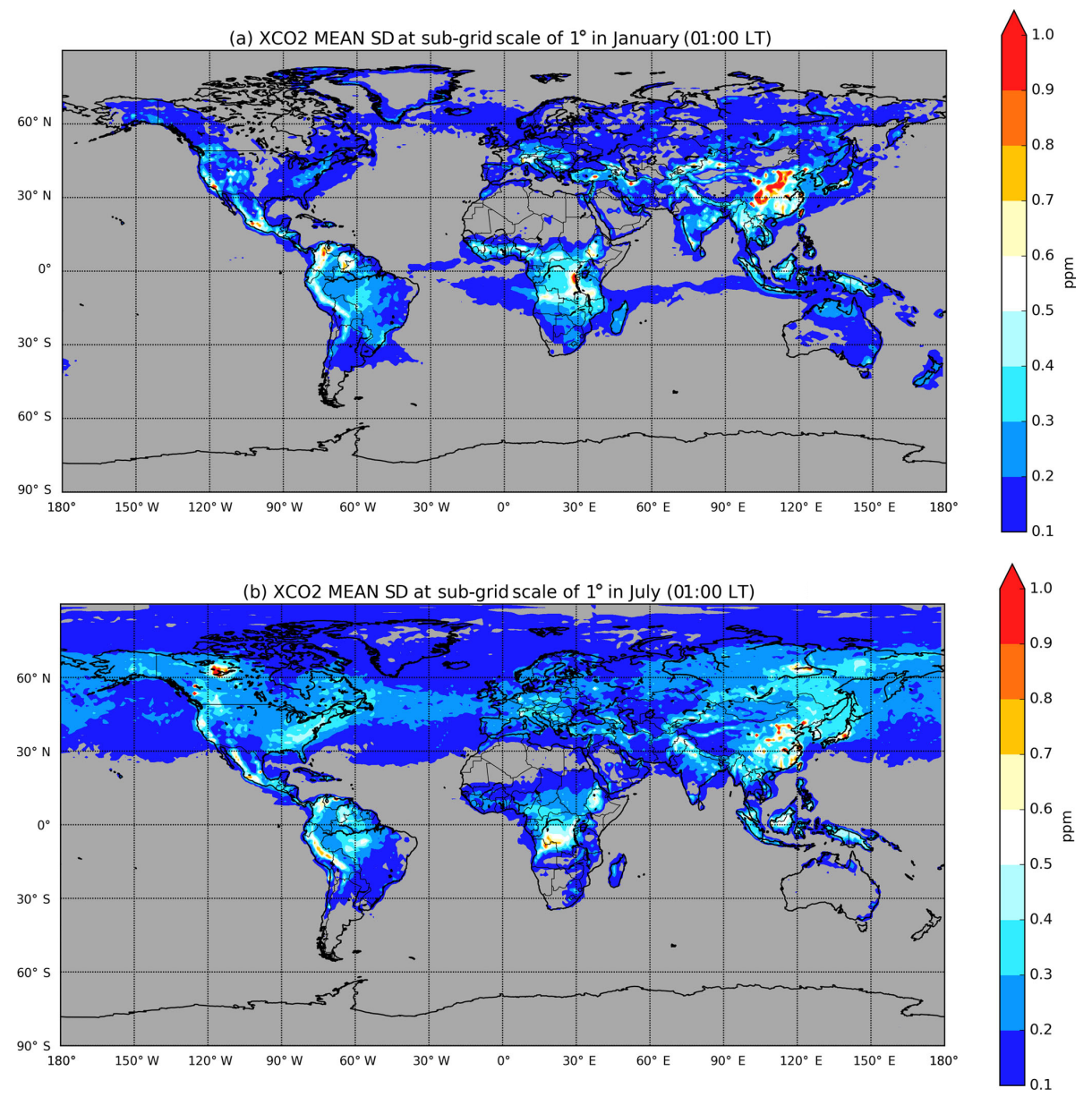

Figure 14. Monthly mean $\mathrm{XCO}_{2}$ small-scale variability $(\sigma)$ within $1^{\circ} \times 1^{\circ}$ grid boxes (ppm) at 01:00 local time in (a) January and (b) July. Grey shading denotes $\sigma<0.1$.

remains trapped by the mountains. These episodes result in large enhancements in $\mathrm{XCO}_{2}$ (Hedelius et al., 2017) and high $\mathrm{CO}_{2}$ anomalies over periods of a few days (e.g. 26 to $30 \mathrm{Jan}$ uary in Fig. 15a). In those stagnant conditions, the 9kmEXP simulation is in much closer agreement with the observed $\mathrm{XCO}_{2}$ peaks than the $80 \mathrm{kmEXP}$ simulation, which overestimates the $\mathrm{XCO}_{2}$ anomalies. This is because at $80 \mathrm{~km}$ resolution there is an effectively uniform emission for the whole LA basin. Note that the $\mathrm{CO}_{2}$ and $\mathrm{XCO}_{2}$ small-scale variability around LA appears to be larger in winter than in summer (Figs. 11 and 14). Without preserving the sharp gradient in emissions between Pasadena and downtown LA, the $\mathrm{CO}_{2}$ accumulation is overestimated in Pasadena.

The atmospheric circulation in summer is mainly controlled by the sea-mountain breeze ( $\mathrm{Lu}$ and Turco, 1994). Daytime advection of anthropogenic $\mathrm{CO}_{2}$-rich air from the city of LA results in $\mathrm{XCO}_{2}$ peaking in the afternoon before it is vented over the mountains (Newman et al., 2013, 2016). The overestimation in the summer $\mathrm{XCO}_{2}$ peaks at $9 \mathrm{~km}$ likely reflects an overestimation of the emissions in downtown LA. The enhancement of $\mathrm{CO}_{2}$ from anthropogenic emissions is larger at 9 than at $80 \mathrm{~km}$ (Fig. S11). This suggests an overestimation of the hotspot emissions over the LA basin in the temporally extrapolated EDGAR inventory, which is smoothed and less noticeable at lower resolution. There are many reasons why the anthropogenic emissions used in the model can be overestimated, including the temporal extrapolation based on country-scale scaling factors and the use of annual constant emissions in EDGAR v4.2 FT2010 instead of seasonally varying emissions (Corbin et al., 2010).

Differences in the sampling location (centre of grid is 3 and $34 \mathrm{~km}$ from station location at 9 and $80 \mathrm{~km}$ respectively) and orography ( $15 \mathrm{~m}$ below and $46 \mathrm{~m}$ below the station height at 9 and $80 \mathrm{~km}$ respectively), as well as differences in flow and local biogenic fluxes can also play a role in explaining the differences between the simulations at 80 and $9 \mathrm{~km}$ resolutions. The results are consistent with previous studies by Feng et al. (2016) and Hedelius et al. (2018). They found that uncertainties in the fluxes and their high-resolution representation in the LA basin are as important as the atmospheric tracer transport in the representation of the $\mathrm{CO}_{2}$ enhancement and its variability in Pasadena. 
(a)
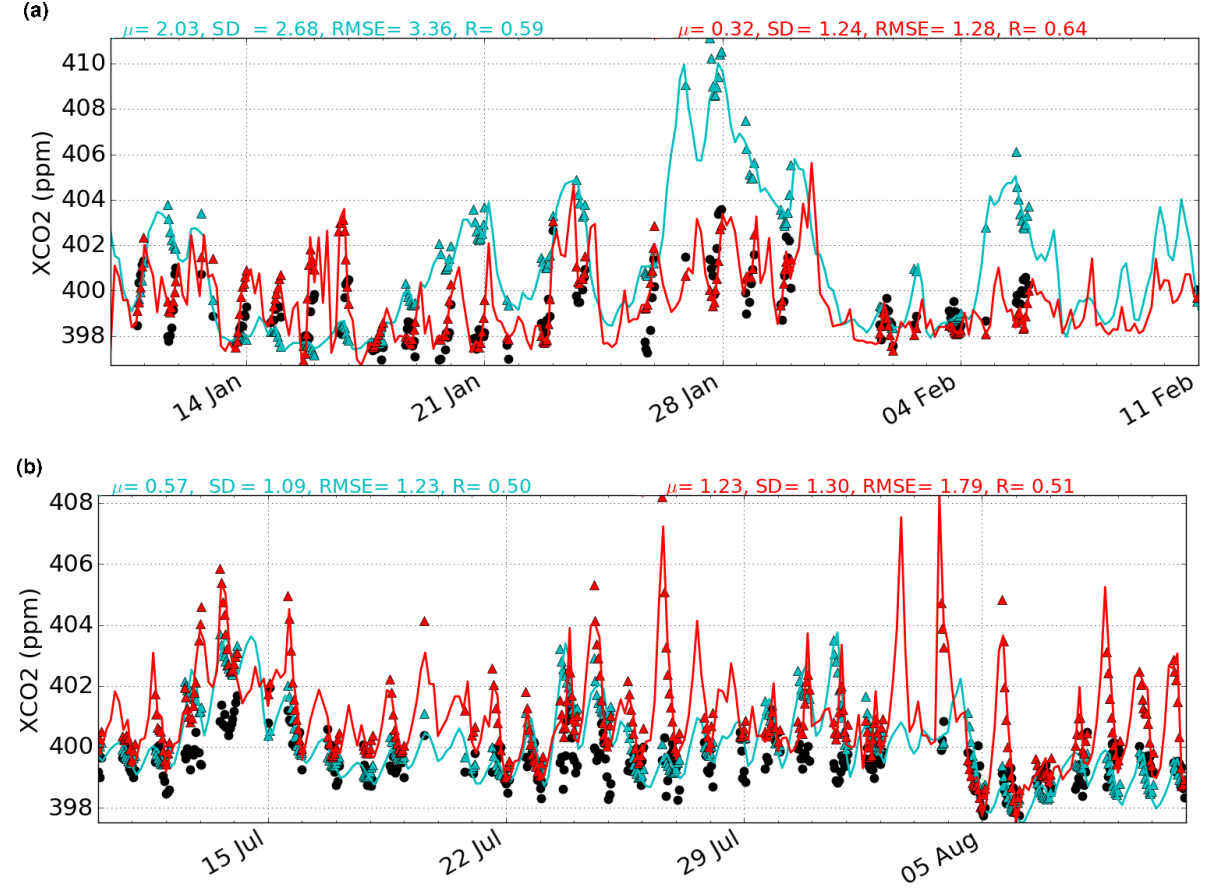

Figure 15. Hourly $\mathrm{XCO}_{2}$ (ppm) at TCCON site of Pasadena (CA, USA) in (a) January and (b) July from 80kmEXP (blue) and 9kmEXP (red) simulations. Hourly observations are shown by black circles. Triangles represent the model XCO2 after smoothing with TCCON averaging kernel and prior. The bias $(\mu)$, standard error (STDE) and Pearson's correlation coefficient $(R)$ from $80 \mathrm{kmEXP}(\mathrm{blue})$ and $9 \mathrm{kmEXP}$ (red) are shown at the top of each panel.

This example at Pasadena highlights the importance of horizontal resolution in representing local gradients of $\mathrm{CO}_{2}$ fluxes in order to reduce the atmospheric $\mathrm{CO}_{2}$ representativeness error. It emphasises that the impact of increasing horizontal resolution is not only to reduce the error of atmospheric $\mathrm{CO}_{2}$ simulations but to enhance the sensitivity of the modelled atmospheric $\mathrm{CO}_{2}$ variability to the $\mathrm{CO}_{2}$ fluxes in urban regions characterised by emission hotspots. Therefore horizontal resolution is crucial for atmospheric inversion systems that aim to estimate anthropogenic emissions.

\section{Discussion and conclusions}

This paper addresses the importance of horizontal resolution in the representation of $\mathrm{CO}_{2}$ variability at diurnal and synoptic scales, referred to here as $\mathrm{CO}_{2}$ weather. The $\mathrm{CO}_{2}$ simulations performed with the ECMWF IFS model allow the combined impact of horizontal resolution associated with (i) the online modelling of the winds, (ii) the numerical tracer transport model and (iii) the spatial-temporal distribution of $\mathrm{CO}_{2}$ fluxes over land to be quantified. The assessment is done by comparing the model errors at various horizontal resolutions with respect to a wide range of observations with hourly resolution and distributed around the globe. The horizontal resolution of the model ranges from $9 \mathrm{~km}$ - as in current operational high-resolution weather and $\mathrm{CO}_{2}$ forecasts at ECMWF
- to $80 \mathrm{~km}$, which corresponds to the ERA-Interim Reanalysis resolution, widely used by many offline tracer transport models. The conclusions to the three main questions addressed in the paper are summarised below.

1. What is the sensitivity of the modelled atmospheric $\mathrm{CO}_{2}$ variability at diurnal and synoptic timescales to horizonal resolution?

The high horizontal resolution of $9 \mathrm{~km}$ leads to a general improvement in the simulated variability of hourly nearsurface and column-averaged atmospheric $\mathrm{CO}_{2}$ compared to the resolution of $80 \mathrm{~km}$. This is shown by a reduction in the mean RMSE of around $1.8 \mathrm{ppm}$ in winter and $3.5 \mathrm{ppm}$ in summer (equivalent to $33 \%$ error reduction) and $0.1 \mathrm{ppm}$ (i.e. around $10 \%$ error reduction) at in situ and TCCON sites respectively, which is associated with a reduction of both the mean and random errors in the model. The inter-station variability is also generally improved in the $9 \mathrm{kmEXP}$ simulation for nearsurface and column-averaged $\mathrm{CO}_{2}$ in January and July, with the standard deviation of station biases reduced up to $50 \%$ compared to the $80 \mathrm{kmEXP}$ simulation in January for near-surface $\mathrm{CO}_{2}$.

Column-averaged $\mathrm{CO}_{2}$ is not as sensitive to horizontal resolution as near-surface $\mathrm{CO}_{2}$ because it has a larger footprint or area of flux influence, except for sites like Pasadena which are close to $\mathrm{CO}_{2}$ emission hotspots. 
Similarly, minimum daily values of atmospheric $\mathrm{CO}_{2}$ are less sensitive to the horizontal resolution than maximum daily values because their footprint tends to be larger in size.

This study also shows that the RMSE reduction with horizontal resolution is not linear. This implies that results from sensitivity studies exploring the impact of resolution based on coarse simulations which show small sensitivity to horizontal resolution cannot be extrapolated to higher horizontal resolutions. These results are consistent with the findings of the Lin et al. (2017) study based on a wider range of model resolutions from $\sim 100$ down to $1 \mathrm{~km}$ and observations at three mountain sites. The reduction in model error associated with the increase of horizontal resolution to $9 \mathrm{~km}$ emanates from four different well-known and connected aspects, as listed below.

a. Better accuracy of the horizontal winds is integral to the reduction of error. The strength of the winds determines the observed $\mathrm{CO}_{2}$ variability i.e. the detected $\mathrm{CO}_{2}$ enhancement - close to emission hotspots like in urban regions (Newman et al., 2013; Xueref-Remy et al., 2018). Therefore, the error in the wind will affect the value of the enhanced $\mathrm{CO}_{2}$ as much as the error in the fluxes. In this context, for example, a wind speed error reduction of $0.5 \mathrm{~m} \mathrm{~s}^{-1}$ - as shown in Sect. 3.1 - across a gradient of 10 ppm per degree - typical of urban areas as shown in Sect. 3.4 - throughout a $6 \mathrm{~h}$ period can result in a $\mathrm{CO}_{2}$ error reduction of around $1 \mathrm{ppm}$. Uncertainty in the winds has been shown to be one of the largest contributors to the uncertainty in the estimated fluxes over urban areas (e.g. Hedelius et al., 2018).

b An overall reduction of the numerical error associated with lower spatial and temporal truncation errors leads to a reduction in tracer advection errors (Prather et al., 2008).

c. There is a general improvement in the horizontal and vertical sampling at the station locations in the model associated with a more realistic representation of orography and coastal boundaries.

d. A more realistic representation of $\mathrm{CO}_{2}$ flux distribution at the surface is key. High resolution gives an increased capability to represent small-scale sharp gradients associated with complex topographical boundaries at coastal and mountainous terrain sites, as well as the presence of strong local surface fluxes of $\mathrm{CO}_{2}$ such as anthropogenic emission hotspots.

2. How is the horizontal resolution affecting the forecast error growth of atmospheric $\mathrm{CO}_{2}$ ?

The horizontal resolution has a consistent positive impact on the error reduction at all forecast lead times, from day 1 to day 10, implying a long-lived improvement in the prediction skill. The RMSE growth is small from days 1 to 4 , namely less than $0.5 \mathrm{ppm}$ near the surface $\mathrm{CO}_{2}$ and less than $0.05 \mathrm{ppm}$ for $\mathrm{XCO}_{2}$. Over the $10 \mathrm{~d}$ there is an increase in RMSE of 1 to $1.5 \mathrm{ppm}$ at the surface and 0.1 to $0.5 \mathrm{ppm}$ for the total column. This error growth is not linear. For example, in July the error of the $1 \mathrm{~d}$ forecast is worse than the $2 \mathrm{~d}$ forecast, with a slower error increase during the 2 to $4 \mathrm{~d}$ forecast and a generally faster error increase from day 5 to day 10 in the forecast. This incoherent change in the error evolution at the beginning of the forecast is likely linked to the strong influence of the biogenic surface fluxes, which respond very fast to changes in temperature, moisture and radiation forcing in the model. Inconsistencies between the initial conditions from the analysis and the model forecast can cause spin-up adjustments which may lead to a degradation of the $1 \mathrm{~d}$ forecast.

Generally, the improvement of forecast skill with increased horizontal resolution is most pronounced in January, when at $9 \mathrm{~km}$ resolution the skill of the $10 \mathrm{~d}$ forecast is better or equal to the accuracy of the $1 \mathrm{~d}$ forecast at $80 \mathrm{~km}$ both near the surface and for the column average $\mathrm{CO}_{2}$. It is likely that the skill of the $10 \mathrm{~d}$ forecast to represent variability of $\mathrm{CO}_{2}$ during summer conditions is hampered by the growing errors in the surface biogenic fluxes during the forecast, as they can be an important contributor to synoptic variability in the summer (Agustí-Panareda et al., 2014).

3. Where and when are the typical representativeness errors associated with unresolved small-scale variability largest?

During daytime, the $\mathrm{CO}_{2}$ small-scale variability of the $9 \mathrm{~km}$ resolution forecast ranges from 1 to $10 \mathrm{ppm}$ at the surface and is an order of magnitude smaller $(0.1$ to $1 \mathrm{ppm}$ ) for the total column average. It points to the areas associated with small-scale gradients where horizontal resolution matters: coastal boundaries and mountain regions have typical values of $5 \mathrm{ppm}$ per degree, and $\mathrm{CO}_{2}$ flux hotspots have the highest variability of up to $10 \mathrm{ppm}$ per degree. During night-time, the small-scale variability tends to be larger than $10 \mathrm{ppm}$ over most areas near the surface, whereas that of column-averaged $\mathrm{CO}_{2}$ shows small differences between day and night.

The high horizontal resolution gives us an insight into the areas with high sensitivity to uncertainty associated with both local tracer transport and fluxes. It is in these areas where improvements in the tracer transport and increased understanding of the heterogeneity and complexity of the surface will be crucial in future model developments. Since these areas are close to emission hotspots, it is clear that in order to monitor $\mathrm{CO}_{2}$ emis- 
sions, particularly from cities and power stations such as in the new Carbon Human Emission project (http: //www.che-project.eu, last access: 30 May 2019), it is paramount to invest in high horizontal resolution models.

Interesting differences are found between surface and column-averaged variability. Near the surface the variability is most pronounced close to emission hotspots and complex terrain. For column-averaged $\mathrm{CO}_{2}$ the subgrid-scale variability is also substantial over the ocean downstream from emissions. This emphasises the importance of the transport influence on $\mathrm{XCO}_{2}$ variability. Small-scale variability is also found to be more pronounced in summer than in winter, as biogenic $\mathrm{CO}_{2}$ fluxes of opposite sign in summer enhance the $\mathrm{CO}_{2}$ gradients in the atmosphere.

In summary, this paper has shown that model simulations using the CAMS $\mathrm{CO}_{2}$ forecasting system at $9 \mathrm{~km}$ resolution can provide a more accurate representation of tracer transport and the local influences of surface fluxes than at lower resolutions ranging from 80 to $16 \mathrm{~km}$, resulting in an overall better representation of the atmospheric $\mathrm{CO}_{2}$ variability at diurnal and synoptic timescales. However, at higher horizontal resolution there is also higher sensitivity of atmospheric $\mathrm{CO}_{2}$ to $\mathrm{CO}_{2}$ flux errors, as emissions and biogenic flux hotspots are not diffused over large areas like in lower-resolution models. Thus, higher-resolution models also risk deterioration in the forecast RMSE, e.g. near emission hotspots associated with larger errors. With the enhancement of the model uncertainty at high resolution, the prospect of further increasing the horizontal resolution needs to be carefully balanced with improvements in the most uncertain model processes.

The impact of horizontal resolution on the accuracy of the winds highlights that errors in the wind need to be considered as an important source of uncertainty both in the atmospheric $\mathrm{CO}_{2}$ analysis and forecast and in the inversion systems (Polavarapu et al., 2016). The findings in this study also suggest that increasing horizontal resolution up to kilometric scales in atmospheric data assimilation and inversion systems would allow the use of more in situ and high-resolution satellite observations close to strong sources and sinks and over complex terrain. Lin et al. (2017) found that a minimum horizontal resolution of $4 \mathrm{~km}$ is required to simulate a realistic diurnal cycle of $\mathrm{CO}_{2}$ at mountain sites.
Currently, the precision of $\mathrm{XCO}_{2}$ from satellite observations is around 1.0 to $1.5 \mathrm{ppm}$ for ACOS-GOSAT data (O'Dell et al., 2012) and OCO-2 data (Wunch et al., 2017). However, if tracer transport models cannot represent their variability accurately in space and time, all the efforts to reduce the errors from the satellite retrievals of $\mathrm{CO}_{2}$ will not be fruitful in their attempt to reduce the uncertainty in the estimation of surface fluxes. This is because relatively small differences in atmospheric mixing ratios are associated with significant differences in surface fluxes (Houweling et al., 2010; Ott et al., 2015). The benefits of high resolution in inversion systems will also need to be balanced with the costs of running a model at such high resolution.

Finally, the CAMS high-resolution forecast running currently at $9 \mathrm{~km}$ resolution can provide benchmarks for other simulations using coarser grids or offline meteorology ( $\mathrm{Yu}$ et al., 2018). Both CAMS analysis and high-resolution forecasts are freely available to users (https://atmosphere. copernicus.eu, last access: 30 May 2019). Potential applications include the estimation of representativeness errors and data selection screening of observations from satellites and in situ stations in data assimilation systems, spatial collocation of $\mathrm{XCO}_{2}$ from satellite and TCCON data for validation purposes (e.g. Guerlet et al., 2013) or as boundary conditions for high-resolution simulations and/or inversions at regional scales.

Data availability. The data are accessible by contacting the corresponding author (anna.agusti-panareda@ecmwf.int). 


\section{Appendix A}

Table A1. Continuous in situ stations (surface and tower) used to evaluate synoptic variability. NA denotes references that are not available. The full names for the abbreviations of the network organisations are provided in Table A2.

\begin{tabular}{|c|c|c|c|c|c|c|}
\hline $\begin{array}{l}\text { Station } \\
\text { ID }\end{array}$ & Lat-long. & $\begin{array}{r}\text { Altitude } \\
\text { (m a.m.s.l.) }\end{array}$ & $\begin{array}{r}\text { Intake } \\
\text { height } \\
\text { (m a.g.l.) }\end{array}$ & Network & Reference & Type \\
\hline alt & $82.45^{\circ} \mathrm{N}, 62.51^{\circ} \mathrm{W}$ & 200 & 10 & ECCC & Worthy et al. (2003) & remote \\
\hline brw & $71.32^{\circ} \mathrm{N}, 156.61^{\circ} \mathrm{W}$ & 11 & 16 & NOAA & Peterson et al. (1986) & coastal \\
\hline cby & $69.01^{\circ} \mathrm{N}, 105.05^{\circ} \mathrm{W}$ & 35 & 12 & $\mathrm{ECCC}$ & NA & continental \\
\hline inu & $68.32^{\circ} \mathrm{N}, 133.53^{\circ} \mathrm{W}$ & 113 & 10 & ECCC & Worthy et al. (2003) & continental \\
\hline pal & $67.97^{\circ} \mathrm{N}, 24.12^{\circ} \mathrm{E}$ & 560 & 5 & FMI & Hatakka et al. (2003) & continental \\
\hline bck & $62.80^{\circ} \mathrm{N}, 116.05^{\circ} \mathrm{W}$ & 179 & 60 & ECCC & NA & continental \\
\hline chl & $58.75^{\circ} \mathrm{N}, 94.07^{\circ} \mathrm{W}$ & 29 & 60 & ECCC & Worthy et al. (2003) & coastal \\
\hline $1 \mathrm{lb}$ & $54.95^{\circ} \mathrm{N}, 112.45^{\circ} \mathrm{W}$ & 540 & 10 & $\mathrm{ECCC}$ & Worthy et al. (2003) & continental \\
\hline etl & $54.35^{\circ} \mathrm{N}, 104.98^{\circ} \mathrm{W}$ & 492 & 105 & ECCC & Worthy et al. (2003) & continental \\
\hline mhd & $53.33^{\circ} \mathrm{N}, 9.90^{\circ} \mathrm{W}$ & 5 & 24 & LSCE & Ramonet et al. (2010) & coastal \\
\hline wao & $52.95^{\circ} \mathrm{N}, 1.12^{\circ} \mathrm{E}$ & 20 & 10 & UEA & Wilson (2013) & coastal \\
\hline ces & $51.97^{\circ} \mathrm{N}, 4.93^{\circ} \mathrm{E}$ & -1 & 200 & $\mathrm{ECN}$ & Vermeulen et al. (2011) & continental \\
\hline est & $51.66^{\circ} \mathrm{N}, 110.21^{\circ} \mathrm{W}$ & 707 & 3 & ECCC & Worthy et al. (2003) & continental \\
\hline fsd & $49.88^{\circ} \mathrm{N}, 81.57^{\circ} \mathrm{W}$ & 210 & 40 & ECCC & Worthy et al. (2003) & continental \\
\hline cps & $49.82^{\circ} \mathrm{N}, 74.98^{\circ} \mathrm{W}$ & 381 & 8 & ECCC & Worthy et al. (2003) & continental \\
\hline esp & $49.38^{\circ} \mathrm{N}, 126.54^{\circ} \mathrm{W}$ & 7 & 40 & ECCC & Worthy et al. (2003) & coastal \\
\hline kas & $49.23^{\circ} \mathrm{N}, 19.98^{\circ} \mathrm{E}$ & 1989 & 5 & AGH & Necki et al. (2003), Rozanski et al. (2014) & mountain \\
\hline ssl & $47.92^{\circ} \mathrm{N}, 7.92^{\circ} \mathrm{E}$ & 1205 & 12 & UBA-SCHAU & Schmidt et al. (2003) & mountain \\
\hline hun & $46.95^{\circ} \mathrm{N}, 16.65^{\circ} \mathrm{E}$ & 248 & 115 & HMS & Haszpra et al. (2001) & continental \\
\hline jfj & $46.55^{\circ} \mathrm{N}, 7.99^{\circ} \mathrm{E}$ & 3570 & 10 & EMPA & Schibig et al. (2015) & mountain \\
\hline lef & $45.95^{\circ} \mathrm{N}, 90.27^{\circ} \mathrm{W}$ & 472 & 396 & NOAA & Andrews et al. (2014) & continental \\
\hline puy & $45.77^{\circ} \mathrm{N}, 2.97^{\circ} \mathrm{E}$ & 1465 & 10 & LSCE & Lopez et al. (2015) & mountain \\
\hline amt & $45.03^{\circ} \mathrm{N}, 68.68^{\circ} \mathrm{W}$ & 53 & 107 & NOAA & Andrews et al. (2014) & continental \\
\hline egb & $44.23^{\circ} \mathrm{N}, 79.78^{\circ} \mathrm{W}$ & 251 & 3 & ECCC & Worthy et al. (2003) & continental \\
\hline wsa & $43.93^{\circ} \mathrm{N}, 60.02^{\circ} \mathrm{W}$ & 5 & 25 & ECCC & Worthy et al. (2003) & remote \\
\hline vac & $42.88^{\circ} \mathrm{N}, 3.21^{\circ} \mathrm{W}$ & 1086 & 20 & ClimaDat & Morguí et al. (2013) & mountain \\
\hline tpd & $42.62^{\circ} \mathrm{N}, 80.55^{\circ} \mathrm{W}$ & 231 & 35 & ECCC & Worthy et al. (2003) & continental \\
\hline dec & $40.74^{\circ} \mathrm{N}, 0.79^{\circ} \mathrm{E}$ & 1 & 10 & ClimaDat & Morguí et al. (2013) & coastal \\
\hline hdp & $40.56^{\circ} \mathrm{N}, 111.65^{\circ} \mathrm{W}$ & 3351 & 17.7 & NCAR & Stephens et al. (2011) & mountain \\
\hline $\mathrm{spl}$ & $40.45^{\circ} \mathrm{N}, 106.73^{\circ} \mathrm{W}$ & 3210 & 9.1 & NCAR & Stephens et al. (2011) & mountain \\
\hline gic & $40.35^{\circ} \mathrm{N}, 5.18^{\circ} \mathrm{W}$ & 1436 & 20 & ClimaDat & Morguí et al. (2013) & mountain \\
\hline nwr & $40.05^{\circ} \mathrm{N}, 105.59^{\circ} \mathrm{W}$ & 3523 & 3.5 & NCAR & Stephens et al. (2011) & mountain \\
\hline bao & $40.05^{\circ} \mathrm{N}, 105.0^{\circ} \mathrm{W}$ & 1584 & 300 & NOAA & Andrews et al. (2014) & continental \\
\hline ryo & $39.03^{\circ} \mathrm{N}, 141.82^{\circ} \mathrm{E}$ & 260 & 20 & JMA & Tsutsumi et al. (2005) & coastal \\
\hline snp & $38.62^{\circ} \mathrm{N}, 78.35^{\circ} \mathrm{W}$ & 1008 & 17 & NOAA & Andrews et al. (2014) & mountain \\
\hline wgc & $38.27^{\circ} \mathrm{N}, 121.49^{\circ} \mathrm{W}$ & 0 & 483 & NOAA & Andrews et al. (2014) & coastal \\
\hline $\mathrm{sgc}$ & $36.70^{\circ} \mathrm{N}, 5.38^{\circ} \mathrm{W}$ & 850 & 20 & ClimaDat & Morguí et al. (2013) & continental \\
\hline sct & $33.41^{\circ} \mathrm{N}, 81.83^{\circ} \mathrm{W}$ & 115 & 305 & NOAA & Andrews et al. (2014) & continental \\
\hline wkt & $31.31^{\circ} \mathrm{N}, 97.33^{\circ} \mathrm{W}$ & 251 & 457 & NOAA & Andrews et al. (2014) & continental \\
\hline izo & $28.31^{\circ} \mathrm{N}, 16.50^{\circ} \mathrm{W}$ & 2373 & 13 & AEMET & Gomez-Pelaez and Ramos (2011) & mountain \\
\hline yon & $24.47^{\circ} \mathrm{N}, 123.02^{\circ} \mathrm{E}$ & 30 & 20 & JMA & Tsutsumi et al. (2005) & coastal \\
\hline $\mathrm{mnm}$ & $24.28^{\circ} \mathrm{N}, 153.98^{\circ} \mathrm{E}$ & 8 & 20 & JMA & Tsutsumi et al. (2005) & remote \\
\hline mlo & $19.54^{\circ} \mathrm{N}, 155.58^{\circ} \mathrm{W}$ & 3397 & 40 & NOAA & Thoning et al. (1989) & mountain \\
\hline smo & $14.25^{\circ} \mathrm{S}, 170.56^{\circ} \mathrm{W}$ & 42 & 10 & NOAA & Halter et al. (1988) & remote \\
\hline cpt & $34.35^{\circ} \mathrm{S}, 18.49^{\circ} \mathrm{E}$ & 230 & 30 & SAWS & Brunke et al. (2004) & coastal \\
\hline ams & $37.80^{\circ} \mathrm{S}, 77.54^{\circ} \mathrm{E}$ & 55 & 20 & LSCE & Gaudry et al. (1991) & remote \\
\hline cgo & $40.68^{\circ} \mathrm{S}, 144.69^{\circ} \mathrm{E}$ & 94 & 70 & CSIRO & Francey et al. (2003) & coastal \\
\hline mqa & $54.50^{\circ} \mathrm{S}, 158.94^{\circ} \mathrm{E}$ & 6 & 10 & CSIRO & Stavert et al. (2018) & remote \\
\hline cya & $66.28^{\circ} \mathrm{S}, 110.52^{\circ} \mathrm{E}$ & 47 & 7 & CSIRO & Loh et al. (2017) & remote \\
\hline syo & $69.01^{\circ} \mathrm{S}, 39.59^{\circ} \mathrm{E}$ & 14 & 8 & TU & NA & remote \\
\hline spo & $89.98^{\circ} \mathrm{S}, 24.80^{\circ} \mathrm{W}$ & 2810 & 10 & NOAA & Conway and Thoning (1990) & remote \\
\hline
\end{tabular}


Table A2. Organisations associated with observing stations.

\begin{tabular}{|c|c|}
\hline Abbreviation & Organisation \\
\hline AEMET & Izaña Atmospheric Research Center, Meteorological State Agency of Spain \\
\hline $\mathrm{AGH}$ & AGH University of Science and Technology, Krakow, Poland \\
\hline BIRA-IASB & Royal Belgian Institute for Space Aeronomy, Brussels, Belgium \\
\hline Caltech & California Institute of Technology \\
\hline ClimaDat & $\begin{array}{l}\text { Land, Atmosphere and Oceans Laboratory at the Institut Català de Ciències del Clima (2010-2016); } \\
\text { at Institut de Ciència i Tecnologia Ambientals, Universitat Autònoma de Barcelona (since 2017) }\end{array}$ \\
\hline CSIRO & Commonwealth Scientific and Industrial Research Organization, Oceans \& Atmosphere \\
\hline ECCC & Environment and Climate Change Canada \\
\hline $\mathrm{ECN}$ & Energy Research Centre of the Netherlands \\
\hline EMPA & Swiss Federal Laboratories for Materials Science and Technology \\
\hline FMI & Finish Meteorological Institute \\
\hline HMS & Hungarian Meteorological Service \\
\hline KIT & Karlsruhe Institute of Technology \\
\hline LSCE & Laboratoire des Sciences du Climat et de l'Environnement \\
\hline MPI-BGC & Max Planck Institute for Biogeochemistry \\
\hline NASA & National Aeronautics and Space Administration \\
\hline JAXA & Japan Aerospace Exploration Agency \\
\hline JMA & Japan Meteorological Agency \\
\hline NIES & National Institute for Environmental Studies \\
\hline NIWA & National Institute of Water and Atmospheric \\
\hline NCAR & National Center For Atmospheric Research \\
\hline NOAA & NOAA Global Monitoring Division \\
\hline SAWS & South African Weather Service \\
\hline TU & Tohoku University \\
\hline UBA-SCHAU & Umweltbundesamt, Schauinsland station \\
\hline UBremen-IUP & Institute of Environmental Physics, Universität Bremen \\
\hline UEA & University of East Anglia \\
\hline UHEI-IUP & University of Heidelberg, Institut für Umweltphysik \\
\hline UOW & University of Wollongong \\
\hline UR & Université de La Réunion \\
\hline
\end{tabular}

Table A3. TCCON stations

\begin{tabular}{lllllll}
\hline Station ID & Latitude-longitude & Altitude $(\mathrm{m})$ & $\mathrm{N}$ data Jan & N data Jul & Organisation & Reference \\
\hline bialystok01 & $53.23^{\circ} \mathrm{N}, 23.02^{\circ} \mathrm{E}$ & 180 & 15 & 68 & UBremen-IUP & Deutscher et al. (2014) \\
bremen01 & $53.10^{\circ} \mathrm{N}, 8.85^{\circ} \mathrm{E}$ & 27 & 8 & 44 & UBremen-IUP & Notholt et al. (2014a) \\
Karlsruhe & $49.10^{\circ} \mathrm{N}, 8.44^{\circ} \mathrm{E}$ & 116 & 33 & 90 & KIT & Hase et al. (2014) \\
orleans01 & $47.97^{\circ} \mathrm{N}, 2.11^{\circ} \mathrm{E}$ & 130 & 67 & 16 & UBremen-IUP & Warneke et al. (2014) \\
garmisch01 & $47.48^{\circ} \mathrm{N}, 11.06^{\circ} \mathrm{E}$ & 740 & 33 & 90 & KIT & Sussmann and Rettinger (2014) \\
parkfalls01 & $45.94^{\circ} \mathrm{N}, 90.27^{\circ} \mathrm{W}$ & 440 & 28 & 168 & Caltech & Wennberg et al. (2014a) \\
rikubetsu01 & $43.46^{\circ} \mathrm{N}, 143.77^{\circ} \mathrm{E}$ & 30 & 21 & 9 & NIES & Morino et al. (2017a) \\
lamont01 & $36.60^{\circ} \mathrm{N}, 97.49^{\circ} \mathrm{W}$ & 320 & 129 & 299 & Caltech & Wennberg et al. (2016) \\
tsukuba02 & $36.05^{\circ} \mathrm{N}, 140.12^{\circ} \mathrm{E}$ & 30 & 111 & 120 & NIES & Morino et al. (2014b) \\
edwards01 & $34.96^{\circ} \mathrm{N}, 117.88^{\circ} \mathrm{W}$ & 699 & 191 & 316 & NASA & Iraci et al. (2016) \\
pasadena01 & $34.14^{\circ} \mathrm{N}, 118.13^{\circ} \mathrm{W}$ & 230 & 160 & 302 & Caltech & Wennberg et al. (2014b) \\
saga01 & $33.24^{\circ} \mathrm{N}, 130.29^{\circ} \mathrm{E}$ & 7 & 30 & 30 & JAXA & Shiomi et al. (2014) \\
izana01 & $28.30^{\circ} \mathrm{N}, 16.48^{\circ} \mathrm{W}$ & 2370 & 43 & 18 & AEMET/KIT & Blumenstock et al. (2014) \\
ascension01 & $7.92^{\circ} \mathrm{S}, 14.33^{\circ} \mathrm{W}$ & 10 & 153 & 158 & MPI-BGC & Feist et al. (2014) \\
darwin01 & $12.43^{\circ} \mathrm{S}, 130.89^{\circ} \mathrm{E}$ & 30 & 34 & 264 & UOW & Griffith et al. (2014a) \\
reunion01 & $20.90^{\circ} \mathrm{S}, 55.49^{\circ} \mathrm{E}$ & 87 & 150 & 136 & BIRA-IASB/UR & De Mazière et al. (2014) \\
wollongong01 & $34.41^{\circ} \mathrm{S}, 150.88^{\circ} \mathrm{E}$ & 30 & 157 & 96 & UOW & Griffith et al. (2014b) \\
lauder02 & $45.04^{\circ} \mathrm{S}, 169.68^{\circ} \mathrm{E}$ & 370 & 104 & 86 & NIWA & Sherlock et al. (2014) \\
\hline
\end{tabular}


Supplement. The supplement related to this article is available online at: https://doi.org/10.5194/acp-19-7347-2019-supplement.

Author contributions. The simulations were performed by AAP. The coding of the mass fixer required for the high-resolution transport in the IFS was done by MD. The concept and ideas to design the high-resolution simulations were devised by FC, AAP, MD, SM and JMS in discussion with RE and VHP. RML, ZL, JAM and RC provided additional observations at crucial sites and guidance on the evaluation of the simulations. CR and DW provided data and input on the interpretation of the model evaluation at the TCCON site of Pasadena. The $\mathrm{CO}_{2}$ validation tools have been developed by SM and AAP. The paper was prepared by AAP with input and feedback from MD, SM, FC, JMS, JB, RE, BL, RML, ZL, JAM, MP, VHP, MR, CR, ATV, TW and DW.

Competing interests. The authors declare that they have no conflict of interest.

Acknowledgements. This research was generated using Copernicus Atmosphere Monitoring Service (2018) information. Anna AgustíPanareda has been partly funded by the $\mathrm{CHE}$ project. The $\mathrm{CHE}$ project has received funding from the European Union's Horizon 2020 Research and Innovation programme under grant agreement no. 776186. Frédéric Chevallier received funding from the Copernicus Atmosphere Monitoring Service, implemented by the European Centre for Medium-Range Weather Forecasts (ECMWF) on behalf of the European Commission. Thanks are given to all the station principal investigators from the numerous individual stations and networks like NOAA, ICOS, AEMET, AGH, CSIRO, ECCC, ECN, EMPA, FMI, HMS, LSCE, NCAR, JMA, MPIBGC, NIWA, SAWS, TU, UBA-SCHAU, UEA, UHEI-IUP, UR, UBremen-IUP, BIRA-IASB, Caltech, KIT, NASA, JAXA, NIES and UOW that contributed their $\mathrm{CO}_{2}$ observations to the cooperative GLOBALVIEWplus (ObsPack , 2015) product and TCCON which are fundamental for the evaluation of the model simulations. The ClimaDat Network has received funding from the "la Caixa" Foundation, under agreement 2010-002624. We are grateful to many colleagues at ECMWF for their support and fruitful discussions, particularly to Gabor Radnoti, Thomas Haiden and Martin Janouseck for their technical support in the evaluation of the winds; Miha Razinger for his technical support in the production of Fig. 1; Johannes Flemming and Zak Kipling for their support in the implementation of the additional $\mathrm{CO}_{2}$ tracers in the IFS model; Sylvie Malardel for her support and discussions on the general aspects of atmospheric tracer modelling in the IFS; and Gianpaolo Balsamo, Souhail Boussetta, Zak Kipling and Johannes Flemming for their technical support in the implementation of a bug fix in the CTESSEL model of biogenic emissions. Many thanks are given to Paul Wennberg (Caltech) for his advice on the use of the TCCON data; Martin Krol (Wageningen University) for his suggestions on the evaluation of the daily maximum $\mathrm{CO}_{2}$; and Britton Stephens (NCAR) for his comments on the mountain site evaluation which helped improve the description of the vertical sampling strategy and emphasise the importance of high resolution at mountain sites.
Financial support. This research has been supported by the Copernicus Atmospheric Monitoring Service and by the European Commission (CHE project, grant no. 776186).

Review statement. This paper was edited by Christoph Gerbig and reviewed by two anonymous referees.

\section{References}

Agustí-Panareda, A., Massart, S., Chevallier, F., Boussetta, S., Balsamo, G., Beljaars, A., Ciais, P., Deutscher, N. M., Engelen, R., Jones, L., Kivi, R., Paris, J.-D., Peuch, V.-H., Sherlock, V., Vermeulen, A. T., Wennberg, P. O., and Wunch, D.: Forecasting global atmospheric $\mathrm{CO}_{2}$, Atmos. Chem. Phys., 14, 1195911983, https://doi.org/10.5194/acp-14-11959-2014, 2014.

Agustí-Panareda, A., Massart, S., Chevallier, F., Balsamo, G., Boussetta, S., Dutra, E., and Beljaars, A.: A biogenic $\mathrm{CO}_{2}$ flux adjustment scheme for the mitigation of large-scale biases in global atmospheric $\mathrm{CO}_{2}$ analyses and forecasts, Atmos. Chem. Phys., 16, 10399-10418, https://doi.org/10.5194/acp-16-103992016, 2016.

Agustí-Panareda, A., Diamantakis, M., Bayona, V., Klappenbach, F., and Butz, A.: Improving the inter-hemispheric gradient of total column atmospheric $\mathrm{CO}_{2}$ and $\mathrm{CH}_{4}$ in simulations with the ECMWF semi-Lagrangian atmospheric global model, Geosci. Model Dev., 10, 1-18, https://doi.org/10.5194/gmd-10-1-2017, 2017.

Ahmadov, R., Gerbig, C., Kretschmer, R., Körner, S., Rödenbeck, C., Bousquet, P., and Ramonet, M.: Comparing high resolution WRF-VPRM simulations and two global $\mathrm{CO}_{2}$ transport models with coastal tower measurements of $\mathrm{CO}_{2}$, Biogeosciences, 6, 807-817, https://doi.org/10.5194/bg-6-807-2009, 2009.

Alkhaled, A. A., Michalak, A. M., and Kawa, S. R.: Using $\mathrm{CO}_{2}$ spatial variability to quantify representation errors of satellite $\mathrm{CO}_{2}$ retrievals, Geophys. Res. Lett., 35, L16813, https://doi.org/10.1029/2008GL034528, 2008.

Andrews, A. E., Kofler, J. D., Trudeau, M. E., Williams, J. C., Neff, D. H., Masarie, K. A., Chao, D. Y., Kitzis, D. R., Novelli, P. C., Zhao, C. L., Dlugokencky, E. J., Lang, P. M., Crotwell, M. J., Fischer, M. L., Parker, M. J., Lee, J. T., Baumann, D. D., Desai, A. R., Stanier, C. O., De Wekker, S. F. J., Wolfe, D. E., Munger, J. W., and Tans, P. P.: $\mathrm{CO}_{2}, \mathrm{CO}$, and $\mathrm{CH}_{4}$ measurements from tall towers in the NOAA Earth System Research Laboratory's Global Greenhouse Gas Reference Network: instrumentation, uncertainty analysis, and recommendations for future high-accuracy greenhouse gas monitoring efforts, Atmos. Meas. Tech., 7, 647687, https://doi.org/10.5194/amt-7-647-2014, 2014.

Bechtold, P., Köhler, M., Jung, T., Doblas-Reyes, F., Leutbecher, M., Rodwell, M., Vitart, F., and Balsamo, G.: Advances in simulating atmospheric variability with the ECMWF model: From synoptic to decadal time-scales, Q. J. Roy. Meteor. Soc., 134, 1337-1351, 2008.

Bechtold, P., Semane, N., Lopez, P., Chaboureau, J.-P., Beljaars, A., and Bormann, N.: Representing equilibrium and nonequilibrium convection in large-scale models, J. Atmos. Sci., 71, 734-753, 2014. 
Belikov, D. A., Maksyutov, S., Ganshin, A., Zhuravlev, R., Deutscher, N. M., Wunch, D., Feist, D. G., Morino, I., Parker, R. J., Strong, K., Yoshida, Y., Bril, A., Oshchepkov, S., Boesch, H., Dubey, M. K., Griffith, D., Hewson, W., Kivi, R., Mendonca, J., Notholt, J., Schneider, M., Sussmann, R., Velazco, V. A., and Aoki, S.: Study of the footprints of short-term variation in $\mathrm{XCO}_{2}$ observed by TCCON sites using NIES and FLEXPART atmospheric transport models, Atmos. Chem. Phys., 17, 143-157, https://doi.org/10.5194/acp-17-143-2017, 2017.

Balzarolo, M., Boussetta, S., Balsamo, G., Beljaars, A., Maignan, F., Calvet, J.-C., Lafont, S., Barbu, A., Poulter, B., Chevallier, F., Szczypta, C., and Papale, D.: Evaluating the potential of large-scale simulations to predict carbon fluxes of terrestrial ecosystems over a European Eddy Covariance network, Biogeosciences, 11, 2661-2678, https://doi.org/10.5194/bg-112661-2014, 2014.

Beljaars, A. and Viterbo, P.: The role of the boundary layer in a numerical weather prediction model, in Clear and cloudy boundary layers, Royal Netherlands Academy of Arts and Sciences, North Holland Publishers, Amsterdam, 1998.

Blumenstock, T., Hase, F., Schneider, M., García, O. E., and Sepúlveda, E.: TCCON data from Izana, Tenerife, Spain, Release GGG2014R1, TCCON data archive, hosted by CaltechDATA, California Institute of Technology, Pasadena, CA, USA, https://doi.org/10.14291/tccon.ggg2014.izana01.R1, 2014.

Boussetta, S., Balsamo, G., Beljaars, A., Agustí-Panareda, A., Calvet, J.-C., Jacobs, C., van den Hurk, B., Viterbo, P., Lafont, S., Dutra, E., Jarlan, L., Balzarolo, M., Papale, D., and van der Werf, G.: Natural carbon dioxide exchanges in the ECMWF Integrated Forecasting System: Implementation and offline validation, J. Geophys. Res.-Atmos., 118, 1-24, https://doi.org/10.1002/jgrd.50488, 2013.

Brooks, B.-G. J., Desai, A. R., Stephens, B. B., Bowling, D. R., Burns, S. P., Watt, A. S., Heck, S. L., and Sweeney, C.: Assessing filtering of mountaintop $\mathrm{CO}_{2}$ mole fractions for application to inverse models of biosphere-atmosphere carbon exchange, Atmos. Chem. Phys., 12, 2099-2115, https://doi.org/10.5194/acp12-2099-2012, 2012.

Brunke, E.-G., Labuschagne, C., Parker, B., Scheel, H. E., and Whittlestone, S.: Baseline air mass selection at Cape Point, South Africa: Application of ${ }^{222} \mathrm{Rn}$ and other filter criteria to $\mathrm{CO}_{2}$, Atmos. Environ., 38, 5693-5702, 2004.

Chevallier, F., Ciais, P., Conway, T. J., Aalto, T., Anderson, B. E., Bousquet, P., Brunke, E. G., Ciattaglia, L., Esaki, Y., Fröhlich, M., Gomez, A., Gomez-Pelaez, A.J., Haszpra, L., Krummel, P. B., Langenfelds, R. L., Leuenberger, M., Machida, T., Maignan, F., Matsueda, H., Morguí, J. A., Mukai, H., Nakazawa, T., Peylin, P., Ramonet, M., Rivier, L., Sawa, Y., Schmidt, M., Steele, L. P., Vay, S. A., Vermeulen, A. T., Wofsy, S., and Worthy, D.: $\mathrm{CO}_{2}$ surface fluxes at grid point scale estimated from a global 21 year reanalysis of atmospheric measurements, J. Geophys. Res., 115, D21307, https://doi.org/10.1029/2010JD013887, 2010.

Chevallier, F., Palmer, P. I., Feng, L., Boesch, H., O’Dell, C. W., and Bousquet, P.: Toward robust and consistent regional $\mathrm{CO}_{2}$ fluxestimates from in situ and spaceborne measurements of atmospheric $\mathrm{CO}_{2}$, Geophys. Res. Lett., 41, 1065-1070, https://doi.org/10.1002/2013GL058772, 2014.
Conway, T. J. and Thoning, K. W.: Short-term variations of atmospheric carbon dioxide at the South Pole, Antarct. J. US, 236238, 1990.

Corbin, K., Denning, A. S., Wang, J.-W., Lu, L., and Baker, I. T.: Possible representation errors in inversions of satellite $\mathrm{CO}_{2}$ retrievals, J. Geophys. Res., 113, D02301, https://doi.org/10.1029/2007JD008716, 2008.

Corbin, K. D., Denning, A. S., and Gurney, K. R.: The space and time impacts on U.S. regional atmospheric $\mathrm{CO}_{2}$ concentrations from a high resolution fossil fuel $\mathrm{CO}_{2}$ emissions inventory, Tellus B, 62, 506-511, https://doi.org/10.1111/j.16000889.2010.00480.x, 2010.

Crisp, D., Pollock, H. R., Rosenberg, R., Chapsky, L., Lee, R. A. M., Oyafuso, F. A., Frankenberg, C., O’Dell, C. W., Bruegge, C. J., Doran, G. B., Eldering, A., Fisher, B. M., Fu, D., Gunson, M. R., Mandrake, L., Osterman, G. B., Schwandner, F. M., Sun, K., Taylor, T. E., Wennberg, P. O., and Wunch, D.: The on-orbit performance of the Orbiting Carbon Observatory-2 (OCO-2) instrument and its radiometrically calibrated products, Atmos. Meas. Tech., 10, 59-81, https://doi.org/10.5194/amt-10-59-2017, 2017.

Dee, D. P., Uppala, S. M., Simmons, A. J., Berrisford, P., Poli, P., Kobayashi, S., Andrae, U., Balmaseda, M. A., Balsamo, G., Bauer, P., Bechtold, P., Beljaars, A. C. M., van de Berg, L., Bidlot, J., Bormann, N., Delsol, C., Dragani, R., Fuentes, M., Geer, A. J., Haimberger, L., Healy, S. B., Hersbach, H., Hólm, E. V., Isaksen, L., Kallberg, P., Köhler, M., Matricardi, M., McNally, A. P., Monge-Sanz, B. M., Morcrette, J.-J., Park, B.-K., Peubey, C., de Rosnay, P., Tavolato, C., Thépaut, J.-N., and Vitart, F.: The ERA-Interim re-analysis: Configuration and performance of the data assimilation system, Q. J. Roy. Meteor. Soc., 137, 553597, https://doi.org/10.1002/qj.828, 2011.

De Mazière, M., Sha, M. K., Desmet, F., Hermans, C., Scolas, F., Kumps, N., Metzger, J.-M., Duflot, V., and Cammas, J.-P.: TCCON data from Reunion Island (La Reunion), France, Release GGG2014R0, TCCON data archive, hosted by CaltechDATA, California Institute of Technology, Pasadena, CA, USA, https://doi.org/10.14291/tccon.ggg2014.reunion01.R0/1149288, 2014.

Deutscher, N., Notholt, J., Messerschmidt, J., Weinzierl, C., Warneke, T., Petri, C., Grupe, P., and Katrynski, K.: TCCON data from Bialystok, Poland, Release GGG2014R1, TCCON data archive, hosted by CaltechDATA, California Institute of Technology, Pasadena, CA, USA, https://doi.org/10.14291/tccon.ggg2014.bialystok01.R1/1183984, 2014.

Diamantakis, M. and Agustí-Panareda, A.: A positive definite tracer mass fixer for high resolution weather and atmospheric composition forecasts, ECMWF Technical Memorandum, No. 819, available at: https://www.ecmwf.int/en/elibrary/17914 positive-definite-tracer-mass-fixer-high-resolution-weather-andatmospheric (last access: 30 May 2019), 2017.

Diamantakis, M. and Magnusson, L.: Sensitivity of the ECMWF model to semi-Lagrangian departure point iterations, Mon. Weather Rev., 144, 3233-3250, https://doi.org/10.1175/MWRD-15-0432.1, 2016.

Feist, D. G., Arnold, S. G., John, N., Geibel, M. C., and Christoph, M.: TCCON data from Ascension Island (SH), Release GGG2014R0, TCCON data archive, hosted by CaltechDATA, California Institute of Technology, Pasadena, CA, USA, 
https://doi.org/10.14291/tccon.ggg2014.ascension01.R0/1149285, 2014.

Feng, S., Lauvaux, T., Newman, S., Rao, P., Ahmadov, R., Deng, A., Díaz-Isaac, L. I., Duren, R. M., Fischer, M. L., Gerbig, C., Gurney, K. R., Huang, J., Jeong, S., Li, Z., Miller, C. E., O'Keeffe, D., Patarasuk, R., Sander, S. P., Song, Y., Wong, K. W., and Yung, Y. L.: Los Angeles megacity: a high-resolution landatmosphere modelling system for urban $\mathrm{CO}_{2}$ emissions, Atmos. Chem. Phys., 16, 9019-9045, https://doi.org/10.5194/acp16-9019-2016, 2016.

Flemming, J., Huijnen, V., Arteta, J., Bechtold, P., Beljaars, A., Blechschmidt, A.-M., Diamantakis, M., Engelen, R. J., Gaudel, A., Inness, A., Jones, L., Josse, B., Katragkou, E., Marecal, V., Peuch, V.-H., Richter, A., Schultz, M. G., Stein, O., and Tsikerdekis, A.: Tropospheric chemistry in the Integrated Forecasting System of ECMWF, Geosci. Model Dev., 8, 975-1003, https://doi.org/10.5194/gmd-8-975-2015, 2015.

Francey, R. J., Steele, L. P., Spencer, D. A., Langenfelds, R. L., Law, R. M., Krummel, P. B., Fraser, P. J., Etheridge, D. M., Derek, N., Coram, S. A., Cooper, L. N., Allison, C. E., Porter, L., and Baly, S.: The CSIRO (Australia) measurement of greenhouse gases in the global atmosphere, report of the 11th WMO/IAEA Meeting of Experts on Carbon Dioxide Concentration and Related Tracer Measurement Techniques, Tokyo, Japan, September 2001, edited by: Toru, S. and Kazuto, S., World Meteorological Organization Global Atmosphere Watch, 97-111, 2003.

Gaudry, A., Monfray, P., Polian, G., Bonsang, G., Ardouin, B., Jegou, A., and Lambert, G.: Non-seasonnal variations of atmospheric $\mathrm{CO}_{2}$ concentrations at Amsterdam Island, Tellus B, 43, 136-143, 1991

Geels, C., Doney, S. C., Dargaville, R., Brandt, J., and Christensen, J. H.: Investigating the sources of synoptic variability in atmospheric $\mathrm{CO}_{2}$ measurements over the Northern Hemisphere continents: a regional model study, Tellus B, 56, 35-50, https://doi.org/10.1111/j.1600-0889.2004.00084.x, 2004.

Gomez-Pelaez, A. J. and Ramos, R.: Improvements in the Carbon Dioxide and Methane Continuous Measurement Programs at Izana Global GAW Station (Spain) during 2007-2009, in: GAW report (No. 194) of the 15th WMO/IAEA Meeting of Experts on Carbon Dioxide, Other Greenhouse Gases, and Related Tracer Measurement Techniques (Jena, Germany; 7-10 September 2009), edited by: Brand, W. A., World Meteorological Organization (TD No. 1553), 133-138, 2011.

Griffith, D. W. T., Deutscher, N., Velazco, V. A., Wennberg, P. O., Yavin, Y., Keppel Aleks, G., Washenfelder, R., Toon, G. C., Blavier, J.-F., Murphy, C., Jones, N., Kettlewell, G., Connor, B., Macatangay, R., Roehl, C., Ryczek, M., Glowacki, J., Culgan, T., and Bryant, G.: TCCON data from Darwin, Australia, Release GGG2014R0, TCCON data archive, hosted by CaltechDATA, California Institute of Technology, Pasadena, CA, USA, https://doi.org/10.14291/tccon.ggg2014.darwin01.R0/1149290, 2014

Griffith, D. W. T., Velazco, V. A., Deutscher, N., Murphy, C., Jones, N., Wilson, S., Macatangay, R., Kettlewell, G., Buchholz, R. R., and Riggenbach, M.: TCCON data from Wollongong, Australia, Release GGG2014R0, TCCON data archive, hosted by CaltechDATA, California Institute of Technology, Pasadena, CA, USA,
https://doi.org/10.14291/tccon.ggg2014.wollongong01.R0/1149291, 2014.

Guerlet, S., Butz, A., Schepers, D., Basu, S., Hasekamp, O.P., Kuze, A., Yokota, T., Blavier, J.-F., Deutscher, N. M., Griffith, D. W. T., Hase, F., Kyro, E., Morino, I., Sherlock, V., Sussmann, R., Galli, A., and Aben, I.: Impact of aerosol and thin cirrus on retrieving and validating $\mathrm{XCO}_{2}$ from GOSAT shortwave infrared measurements, J. Geophys. Res.-Atmos., 118, 48874905, https://doi.org/10.1002/jgrd.50332, 2013.

Gurney, K. R., Law, R. M., Denning, A. S., Rayner, P. J., Baker, D., Bousquet, P., Bruhwiler, L., Chen, Y.-H., Ciais, P., Fan, S., Fung, I. Y., Gloor, M., Heimann, M., Higuchi, K., John, J., Kowalczyk, E., Maki, T., Maksyutov, S., Peylin, P., Prather, M., Pak, B. C., Sarmiento, J., Taguchi, S., Takahashi, T., and Yuen, C.-W.: TransCom 3 inversion intercomparison: 1. Annual mean control results and sensitivity to transport and prior flux information, Tellus B, 55, 555-579, 2003.

Haiden, T., Janousek, M., Bidlot, J.-R., Ferranti, L., Prates, F., Vitart, F., Bauer, P., and Richardson, D.: Evaluation of ECMWF forecasts, including 2016-2017 upgrades, ECMWF Technical Memorandum, No. 817, ECMWF, available at: https://www.ecmwf.int/en/elibrary/ 17913-evaluation-ecmwf-forecasts-includuing-2016-2017-upgrades (last access: 30 May 2019), 2017.

Halter, B. and Harris, J. M.: On the variability of atmospheric carbon dioxide concentration at Barrow, Alaska, during winter, J. Geophys. Res., 88, 6858-6864, 1983.

Halter, B. C., Harris, J. M., and Conway, T. J.: Component signals in the record of atmospheric carbon dioxide concentration at American Samoa, J. Geophys. Res., 93, 15914-15918, 1988.

Hase, F., Blumenstock, T., Dohe, S., Groß, J., and Kiel, M.: TCCON data from Karlsruhe, Germany, Release GGG2014R1, TCCON data archive, hosted by CaltechDATA, California Institute of Technology, Pasadena, CA, USA, https://doi.org/10.14291/tccon.ggg2014.karlsruhe01.R1/1182416, 2014.

Haszpra, L., Barcza, Z., Bakwin, P. S., Berger, B. W., Davis, K. J., and Weidinger, T.: Measuring system for the long-term monitoring of biosphere/atmosphere exchange of carbon dioxide, J. Geophys. Res., 106, 3057-3070, 2001.

Hatakka, J., Aalto, T., Aaltonen, V., Aurela, M., Hakola, H., Komppula, M., Laurila, T., Lihavainen, H., Paatero, J., Salminen, K., and Viisanen, Y.: Overview of the atmospheric research activities and results at Pallas GAW station, Boreal Environ. Res., 8, 365-384, 2003.

Hedelius, J. K., Feng, S., Roehl, C. M., Wunch, D., Hillyard, P. W., Podolske, J. R., Iraci, L. T., Patarasuk, R., Rao, P., O'Keeffe, D., Gurney, K. R., Lauvaux, T., and Wennberg, P. O.: Emissions and topographic effects on column $\mathrm{CO}_{2}\left(\mathrm{XCO}_{2}\right)$ variations, with a focus on the Southern California Megacity, J. Geophys. Res.-Atmos., 122, 7200-7215, https://doi.org/10.1002/2017JD026455, 2017.

Hedelius, J. K., Liu, J., Oda, T., Maksyutov, S., Roehl, C. M., Iraci, L. T., Podolske, J. R., Hillyard, P. W., Liang, J., Gurney, K. R. Wunch, D., and Wennberg, P. O.: Southern California megacity $\mathrm{CO}_{2}, \mathrm{CH}_{4}$, and $\mathrm{CO}$ flux estimates using ground- and spacebased remote sensing and a Lagrangian model, Atmos. Chem. Phys., 18, 16271-16291, https://doi.org/10.5194/acp-18-162712018, 2018. 
Holm, E., Forbes, R., Lang, S., Magnusson, L., and Malardel, S.: New model cycle brings higher resolution, ECMWF Newsletter, No. 147, available at: https://www.ecmwf.int/ en/elibrary/16299-newsletter-no-147-spring-2016 (last access: 30 May 2019), 2016.

Houweling, S., Aben, I., Breon, F.-M., Chevallier, F., Deutscher, N., Engelen, R., Gerbig, C., Griffith, D., Hungershoefer, K., Macatangay, R., Marshall, J., Notholt, J., Peters, W., and Serrar, S.: The importance of transport model uncertainties for the estimation of $\mathrm{CO}_{2}$ sources and sinks using satellite measurements, Atmos. Chem. Phys., 10, 9981-9992, https://doi.org/10.5194/acp-10-9981-2010, 2010.

Inness, A., Ades, M., Agustí-Panareda, A., Barré, J., Benedictow, A., Blechschmidt, A.-M., Dominguez, J. J., Engelen, R., Eskes, H., Flemming, J., Huijnen, V., Jones, L., Kipling, Z., Massart, S., Parrington, M., Peuch, V.-H., Razinger, M., Remy, S., Schulz, M., and Suttie, M.: The CAMS reanalysis of atmospheric composition, Atmos. Chem. Phys., 19, 3515-3556, https://doi.org/10.5194/acp-19-3515-2019, 2019.

Inoue, M., Morino, I., Uchino, O., Nakatsuru, T., Yoshida, Y., Yokota, T., Wunch, D., Wennberg, P. O., Roehl, C. M., Griffith, D. W. T., Velazco, V. A., Deutscher, N. M., Warneke, T., Notholt, J., Robinson, J., Sherlock, V., Hase, F., Blumenstock, T., Rettinger, M., Sussmann, R., Kyrö, E., Kivi, R., Shiomi, K., Kawakami, S., De Mazière, M., Arnold, S. G., Feist, D. G., Barrow, E. A., Barney, J., Dubey, M., Schneider, M., Iraci, L. T., Podolske, J. R., Hillyard, P. W., Machida, T., Sawa, Y., Tsuboi, K., Matsueda, H., Sweeney, C., Tans, P. P., Andrews, A. E., Biraud, S. C., Fukuyama, Y., Pittman, J. V., Kort, E. A., and Tanaka, T.: Bias corrections of GOSAT SWIR $\mathrm{XCO}_{2}$ and $\mathrm{XCH}_{4}$ with TC$\mathrm{CON}$ data and their evaluation using aircraft measurement data, Atmos. Meas. Tech., 9, 3491-3512, https://doi.org/10.5194/amt9-3491-2016, 2016.

Iraci, L. T., Podolske, J., Hillyard, P. W., Roehl, C., Wennberg, P. O., Blavier, J.-F., Allen, N., Wunch, D., Osterman, G. B., and Albertson, R., TCCON data from Edwards (US), Release GGG2014R1, TCCON data archive, hosted by CaltechDATA, California Institute of Technology, Pasadena, CA, USA, https://doi.org/10.14291/tccon.ggg2014.edwards01.R1/1255068, 2016.

Kaiser, J. W., Heil, A., Andreae, M. O., Benedetti, A., Chubarova, N., Jones, L., Morcrette, J.-J., Razinger, M., Schultz, M. G., Suttie, M., and van der Werf, G. R.: Biomass burning emissions estimated with a global fire assimilation system based on observed fire radiative power, Biogeosciences, 9, 527-554, https://doi.org/10.5194/bg-9-527-2012, 2012.

Keeling, C. D., Bacastow, R. B., Bainbridge, A. E., Ekdahl, C. A., Guenther, P. R., Waterman, L. S., and Chin, J. F.: Atmospheric carbon dioxide variations at Mauna Loa Observatory, Hawaii, Tellus, 28, 538-551, https://doi.org/10.1111/j.21533490.1976.tb00701.x, 1976.

Keppel-Aleks, G., Wennberg, P. O., and Schneider, T.: Sources of variations in total column carbon dioxide, Atmos. Chem. Phys., 11, 3581-3593, https://doi.org/10.5194/acp-11-35812011, 2011.

Keppel-Aleks, G., Wennberg, P. O., Washenfelder, R. A., Wunch, D., Schneider, T., Toon, G. C., Andres, R. J., Blavier, J.-F., Connor, B., Davis, K. J., Desai, A. R., Messerschmidt, J., Notholt, J., Roehl, C. M., Sherlock, V., Stephens, B. B., Vay, S. A., and
Wofsy, S. C.: The imprint of surface fluxes and transport on variations in total column carbon dioxide, Biogeosciences, 9, 875891, https://doi.org/10.5194/bg-9-875-2012, 2012.

Koehler, M., Ahlgrimm, M., and Beljaars, A.: Unified treatment of dry convective and stratocumulus-topped boundary layers in the ecmwf model, Q. J. Roy. Meteor. Soc., 137, 43-57, 2011.

Kuze, A., Suto, H., Nakajima, M., and Hamazaki, T.: Thermal and near infrared sensor for carbon observation Fourier-transform spectrometer on the Greenhouse Gases Observing Satellite for greenhouse gases monitoring, Appl. Optics, 48, 6716-6733, 2009.

Law, R. M., Peters, W., Rödenbeck, C., Aulagnier, C., Baker, I., Bergmann, D. J., Bousquet, P., Brandt, J., Bruhwiler, L., Cameron-Smith, P. J., Christensen, J. H., Delage, F., Denning, A. S., Fan, S., Geels, C., Houweling, S., Imasu, R., Karstens, U., Kawa, S. R., Kleist, J., Krol, M. C., Lin, S.J., Lokupitiya, R., Maki, T., Maksyutov, S., Niwa, Y., Onishi, R., Parazoo, N., Patra, P. K., Pieterse, G., Rivier, L., Satoh, M., Serrar, S., Taguchi, S., Takigawa, M., Vautard, R., Vermeulen, A. T., and Zhu, Z.: TransCom model simulations of hourly atmospheric $\mathrm{CO}_{2}$ : Experimental overview and diurnal cycle results for 2002, Global Biogeochem. Cy., 22, GB3009, https://doi.org/10.1029/2007GB003050, 2008.

Law, R. M., Steele, L. P., Drummel, P. B., and Zahorowski, W.: Synoptic variations in atmospheric $\mathrm{CO}_{2}$ at Cape Grim: a model intercomparison, Tellus B, 62, 810-820, 2010.

Lin, J. C., Mallia, D. V., Wu, D., and Stephens, B. B.: How can mountaintop $\mathrm{CO}_{2}$ observations be used to constrain regional carbon fluxes?, Atmos. Chem. Phys., 17, 5561-5581, https://doi.org/10.5194/acp-17-5561-2017, 2017.

Lin, X., Ciais, P., Bousquet, P., Ramonet, M., Yin, Y., Balkanski, Y., Cozic, A., Delmotte, M., Evangeliou, N., Indira, N. K., Locatelli, R., Peng, S., Piao, S., Saunois, M., Swathi, P. S., Wang, R., Yver-Kwok, C., Tiwari, Y. K., and Zhou, L.: Simulating $\mathrm{CH}_{4}$ and $\mathrm{CO}_{2}$ over South and East Asia using the zoomed chemistry transport model LMDz-INCA, Atmos. Chem. Phys., 18, 94759497, https://doi.org/10.5194/acp-18-9475-2018, 2018.

Lin, Y.-L.: Mesoscale Dynamics, Cambridge University Press, Cambridge, https://doi.org/10.1017/CBO9780511619649, 2007.

Locatelli, R., Bousquet, P., Chevallier, F., Fortems-Cheney, A., Szopa, S., Saunois, M., Agusti-Panareda, A., Bergmann, D., Bian, H., Cameron-Smith, P., Chipperfield, M. P., Gloor, E., Houweling, S., Kawa, S. R., Krol, M., Patra, P. K., Prinn, R. G., Rigby, M., Saito, R., and Wilson, C.: Impact of transport model errors on the global and regional methane emissions estimated by inverse modelling, Atmos. Chem. Phys., 13, 9917 9937, https://doi.org/10.5194/acp-13-9917-2013, 2013.

Loh, Z. M., Law, R. M., Ziehn, T., van der Schoot, M. V., Krummel, P. B., Steele, L. P., Etheridge, D. M., Spencer, D. A., Gregory, R. L., Langenfelds, R. L., Stavert, A. R., and Thornton, D. P.: The Australian Greenhouse Gas Observation Network: Current status and vision for the future. 10th International Carbon Dioxide Conference (ICDC10), 21-25 August 2017, Interlaken, Switzerland, available at: http://www.icdc10.unibe.ch/unibe/ portal/fak_naturwis/micro_icdc10/content/e342182/e604227/ e604229/files623284/Loh_Zoe.pdf (last access: 30 May 2019), 2017.

Lopez, M., Schmidt, M., Ramonet, M., Bonne, J.-L., Colomb, A., Kazan, V., Laj, P., and Pichon, J.-M.: Three years of semi- 
continuous greenhouse gas measurements at the Puy de Dôme station (central France), Atmos. Meas. Tech., 8, 3941-3958, https://doi.org/10.5194/amt-8-3941-2015, 2015.

Lu, R. and Turco, R. P.: Air pollutant transport in a coastal environment. Part I: Two dimensional simulations of sea-breeze and mountain effects, J. Atmos. Sci., 51, 2285-2308, 1994.

Malardel, S., Wedi, N., Deconinck, W., Diamantakis, M., Kühnlein, C., Mozdzynski, G., Hamrud, M., and Smolarkiewicz, P.: A new grid for the IFS, ECMWF Newsletter No. 146, available at: https://www.ecmwf.int/sites/default/files/elibrary/ 2016/15041-newsletter-no-146-winter-201516.pdf (last access: 30 May 2019), 2016.

Massart, S., Agustí-Panareda, A., Heymann, J., Buchwitz, M., Chevallier, F., Reuter, M., Hilker, M., Burrows, J. P., Deutscher, N. M., Feist, D. G., Hase, F., Sussmann, R., Desmet, F., Dubey, M. K., Griffith, D. W. T., Kivi, R., Petri, C., Schneider, M., and Velazco, V. A.: Ability of the 4-D-Var analysis of the GOSAT BESD $\mathrm{XCO}_{2}$ retrievals to characterize atmospheric $\mathrm{CO}_{2}$ at large and synoptic scales, Atmos. Chem. Phys., 16, 16531671, https://doi.org/10.5194/acp-16-1653-2016, 2016.

Miller, C. E., Crisp, D., DeCola, P. L., Olsen, S. C., Randerson, J. T., Michalak, A. M., Alkhaled, A., Rayner, P., Jacob, D. J., Suntharalingam, P., Jones, D. B. A., Denning, A. S., Nicholls, M. E., Doney, S. C., Pawson, S., Boesch, H., Connor, B. J., Fung, I. Y., O'Brien, D., Salawitch, R. J., Sander, S. P., Sen, B., Tans, P., Toon, G. C., Wennberg, P. O., Wofsy, S. C., Yung, Y. L., and Law, R. M.: Precision requirements for space-based $\mathrm{XCO}_{2}$ data, J. Geophys. Res., 112, D10314, https://doi.org/10.1029/2006JD007659, 2007.

Morcrette, J.-J., Boucher, O., Jones, L., Salmond, D., Bechtold, P., Beljaars, A., Benedetti, A., Bonet, A., Kaiser, J. W., Razinger, M., Schulz, M., Serrar, S., Simmons, A. J., Sofiev, M., Suttie, M., Tompkins, A. M., and Untch, A.: Aerosol analysis and forecast in the European Centre for Medium-Range Weather Forecasts Integrated Forecast System: forward modeling, J. Geophys. Res., 114, D06206, https://doi.org/10.1029/2008JD011235, 2009.

Morguí, J. A., Àgueda, A., Batet, O., Curcoll, R., Ealo, M., Grossi, C., Occhipinti, P., Sanchez-Garcia, L., Arias, R., and Rodo, X.: ClimaDat: A long-term network to study at different scales climatic processes and interactions between climatic compartments, Geophys. Res. Abstr., EGU13-10265, EGU General Assembly 2013, Vienna, Austria, 2013.

Morguí, J. A., Curcoll, R., and Agustí-Panareda, A.: Using the CLIMADAT atmospheric $\mathrm{CO}_{2}$ dataset to evaluate (CAMS) the performance of a transport model over the Iberian Peninsula, 10th International Carbon Dioxide Conference (ICDC10) Theme 1.2: The contemporary carbon cycle - Emerging approaches and novel observation techniques, 21-25 August 2017, Interlaken, Switzerland, available at: http://www.icdc10.unibe. ch/unibe/portal/fak_naturwis/micro_icdc10/content/e342182/ e588294/e591299/ICDC10_Abstracts_14082017.pdf (last access: 30 May 2019), 2017.

Morino, I., Yokozeki, Y., Matzuzaki, T., and Shishime, A.: TCCON data from Rikubetsu, Hokkaido, Japan, Release GGG2014R1, TCCON data archive, hosted by CaltechDATA, California Institute of Technology, Pasadena, CA, USA, https://doi.org/10.14291/tccon.ggg2014.rikubetsu01.R1/1242265, $2017 \mathrm{a}$.
Morino, I., Matsuzaki, T., and Shishime, A.: TCCON data from Tsukuba, Ibaraki, Japan, 125HR, Release GGG2014R1, TCCON data archive, hosted by CaltechDATA, California Institute of Technology, Pasadena, CA, USA, https://doi.org/10.14291/tccon.ggg2014.tsukuba02.R1/1241486, 2014b.

Necki, J., Schmidt, M., Rozanski, K., Zimnoch, M., Korus, A., Lasa, J., Graul, R., and Levin, I.: Six-year record of atmospheric carbon dioxide and methane at a high-altitude mountain site in Poland, Tellus B, 55, 94-104, 2003.

Newman, S., Jeong, S., Fischer, M. L., Xu, X., Haman, C. L., Lefer, B., Alvarez, S., Rappenglueck, B., Kort, E. A., Andrews, A. E., Peischl, J., Gurney, K. R., Miller, C. E., and Yung, Y. L.: Diurnal tracking of anthropogenic $\mathrm{CO}_{2}$ emissions in the Los Angeles basin megacity during spring 2010, Atmos. Chem. Phys., 13, 4359-4372, https://doi.org/10.5194/acp-13-4359-2013, 2013.

Newman, S., Xu, X., Gurney, K. R., Hsu, Y. K., Li, K. F., Jiang, X., Keeling, R., Feng, S., O’Keefe, D., Patarasuk, R., Wong, K. W., Rao, P., Fischer, M. L., and Yung, Y. L.: Toward consistency between trends in bottom-up $\mathrm{CO}_{2}$ emissions and top-down atmospheric measurements in the Los Angeles megacity, Atmos. Chem. Phys., 16, 3843-3863, https://doi.org/10.5194/acp16-3843-2016, 2016.

Notholt, J., Petri, C., Warneke, T., Deutscher, N., Buschmann, M., Weinzierl, C., Macatangay, R., and Grupe,P.: TCCON data from Bremen, Germany, Release GGG2014R0, TCCON data archive, hosted by CaltechDATA, California Institute of Technology, Pasadena, CA, USA, https://doi.org/10.14291/tccon.ggg2014.bremen01.R0/1149275, 2014a.

ObsPack: Cooperative Global Atmospheric Data Integration Project, Multi-laboratory compilation of atmospheric carbon dioxide data for the period 1968-2014, obspack_co2_1_GLOBALVIEWplus_v1.0_2015-07-30, NOAA Earth System Research Laboratory, Global Monitoring Division, https://doi.org/10.15138/G3RP42, 2015.

O’Dell, C. W., Connor, B., Bösch, H., O’Brien, D., Frankenberg, C., Castano, R., Christi, M., Eldering, D., Fisher, B., Gunson, M., McDuffie, J., Miller, C. E., Natraj, V., Oyafuso, F., Polonsky, I., Smyth, M., Taylor, T., Toon, G. C., Wennberg, P. O., and Wunch, D.: The ACOS $\mathrm{CO}_{2}$ retrieval algorithm - Part 1: Description and validation against synthetic observations, Atmos. Meas. Tech., 5, 99-121, https://doi.org/10.5194/amt-5-99-2012, 2012.

Olivier, J. and Janssens-Maenhout, G.: $\mathrm{CO}_{2}$ Emissions from Fuel Combustion - 2012 Edition, IEA $\mathrm{CO}_{2}$ report 2012, Part III, Greenhouse-Gas Emissions, ISBN 978-92-64-174757, available at: https://edgar.jrc.ec.europa.eu/overview.php?v= CO2ts1990-2014 (last access: 30 May 2019), 2015.

Ott, L. E., Pawson, S., Collatz, G. J., Gregg, W. W., Menemenlis, D., Brix, H., Rousseaux, C. S., Bowman, K. W., Liu, J., Eldering, A., Gunson, M. R., and Kawa, S. R.: Assessing the magnitude of $\mathrm{CO}_{2}$ flux uncertainty in atmospheric $\mathrm{CO}_{2}$ records using products from NASA's Carbon Monitoring Flux Pilot Project, J. Geophys. Res.-Atmos., 120, 734-765, https://doi.org/10.1002/2014JD022411, 2015.

Parazoo, N. C., Denning, A. S., Berry, J. A., Wolf, A., Randall, D. A., Kawa, S. R., Pauluis, S. R., and Doney, S. C.: Moist synoptic transport of $\mathrm{CO}_{2}$ along the mid-latitude storm track, Geophys. 
Res. Lett., 38, L09804, https://doi.org/10.1029/2011GL047238, 2011.

Patra, P. K., Law, R. M., Peters, W., Rödenbeck, C., Takigawa, M., Aulagnier, C., Baker, I., Bergmann, D. J., Bousquet, P., Brandt, J., Bruhwiler, L., Cameron-Smith, P. J., Christensen, J. H., Delage, F., Denning, A. S., Fan, S., Geels, C., Houweling, S., Imasu, R., Karstens, U., Kawa, S. R., Kleist, J., Krol, M. C., Lin, S.-J., Lokupitiya, R., Maki, T., Maksyutov, S., Niwa, Y., Onishi, R., Parazoo, N., Pieterse, G., Rivier, L., Satoh, M., Serrar, S., Taguchi, S., Vautard, R., Vermeulen, A. T., and Zhu, Z.: Transcom model simulations of hourly atmospheric $\mathrm{CO}_{2}$ : analysis of synoptic scale variations for the period 2002-2003, Global Biogeochem. Cy., 22, GB4013, https://doi.org/10.1029/2007GB003081, 2008.

Peterson, J. T., Komhyr, W. D., Waterman, L. S., Gammon, R. H., Thoning, K. W., and Conway, T. J.: Atmospheric $\mathrm{CO}_{2}$ variations at Barrow, Alaska, 1973-1982, J. Atmos. Chem., 4, 491-510, 1986.

Pillai, D., Gerbig, C., Marshall, J., Ahmadov, R., Kretschmer, R., Koch, T., and Karstens, U.: High resolution modeling of $\mathrm{CO}_{2}$ over Europe: implications for representation errors of satellite retrievals, Atmos. Chem. Phys., 10, 83-94, https://doi.org/10.5194/acp-10-83-2010, 2010.

Pillai, D., Gerbig, C., Ahmadov, R., Rödenbeck, C., Kretschmer, R., Koch, T., Thompson, R., Neininger, B., and Lavrié, J. V.: High-resolution simulations of atmospheric $\mathrm{CO}_{2}$ over complex terrain - representing the Ochsenkopf mountain tall tower, Atmos. Chem. Phys., 11, 7445-7464, https://doi.org/10.5194/acp11-7445-2011, 2011.

Polavarapu, S. M., Neish, M., Tanguay, M., Girard, C., de Grandpré, J., Semeniuk, K., Gravel, S., Ren, S., Roche, S., Chan, D., and Strong, K.: Greenhouse gas simulations with a coupled meteorological and transport model: the predictability of $\mathrm{CO}_{2}$, Atmos. Chem. Phys., 16, 12005-12038, https://doi.org/10.5194/acp-1612005-2016, 2016.

Prather, M. J., Zhu, X., Strahan, S. E., Steenrod, S. D., and Rodriguez, S. M.: Quantifying errors in trace species transport modeling, P. Natl. Acad. Sci. USA, 105, 19617-19621, https://doi.org/10.1073/pnas.0806541106, 2008.

Rabier, F., Järvinen, H., Klinker, E., Mahfouf, J.-F., and Simmons, A.: The ECMWF operational implementation of fourdimensional variational assimilation. part I: Experimental results with simplified physics, Q. J. Roy. Meteor. Soc., 126, 11431170, 2000.

Ramonet, M., Ciais, P., Aalto, T., Aulagnier, C., Chevallier, F., Cipriano, D., Conway, T. J., Haszpra, L., Kazan, V., Meinhardt, F., Paris, J.-D., Schmidt, M., Simmonds, P., XuerefRemy, I., and Necki, J.: A recent build-up of atmospheric $\mathrm{CO}_{2}$ over Europe. Part 1: observed signals and possible explanations, Tellus B, 62, 1-13, https://doi.org/10.1111/j.16000889.2009.00442.x, 2010.

Rayner, P. J., Scholze, M., Knorr, W., Kaminski, T., Giering, R., and Widmann, H.: Two decades of terrestrial carbon fluxes from a carbon cycle data assimilation system (CCDAS), Global Biogeochem. Cy., 19, GB2026, https://doi.org/10.1029/2004GB002254, 2005.

Remaud, M., Chevallier, F., Cozic, A., Lin, X., and Bousquet, P.: On the impact of recent developments of the $\mathrm{LMDz}$ atmospheric general circulation model on the simula- tion of $\mathrm{CO}_{2}$ transport, Geosci. Model Dev., 11, 4489-4513, https://doi.org/10.5194/gmd-11-4489-2018, 2018.

Rozanski, K., Necki, J., Chmura, L., Sliwka, I., Zimnoch, M., Bielewski, J., Galkowski, M.,Bartyzel J., and Rosiek, J.: Anthropogenic changes of $\mathrm{CO}_{2}, \mathrm{CH}_{4}, \mathrm{~N}_{2} \mathrm{O}, \mathrm{CFCl} 3, \mathrm{CF} 2 \mathrm{Cl} 2$, $\mathrm{CCl} 2 \mathrm{FCClF} 2, \mathrm{CHCl} 3, \mathrm{CH} 3 \mathrm{CCl} 3, \mathrm{CCl} 4, \mathrm{SF} 6$ and SF5CF3 mixing ratios in the atmosphere over southern Poland, Geol. Q., 58, 673-684, 2014.

Sandu, I., Beljaars, A., Bechtold, P., Mauritsen, T., and Balsamo, G.: Why is it so difficult to represent stably stratified conditions in numerical weather prediction (NWP) models?, J. Adv. Model. Earth Sy., 5, 1-17, https://doi.org/10.1002/jame.20013, 2013.

Schibig, M. F., Steinbacher, M., Buchmann, B., van der LaanLuijkx, I. T., van der Laan, S., Ranjan, S., and Leuenberger, M. C.: Comparison of continuous in situ $\mathrm{CO}_{2}$ observations at Jungfraujoch using two different measurement techniques, Atmos. Meas. Tech., 8, 57-68, https://doi.org/10.5194/amt-8-572015, 2015.

Schmidt, M., Graul, R., Sartorius, H., and Levin, L.: The Schauinsland $\mathrm{CO}_{2}$ record: 30 years of continental observations and their implications for the variability of the European $\mathrm{CO}_{2}$ budget, $\mathrm{J}$. Geophys. Res.-Atmos., 108, 4619-4626, 2003.

Sekiyama, T., Kunii, M., Kajino, M., and Shimbori, T.: Horizontal Resolution Dependence of Atmospheric Simulations of the Fukushima Nuclear Accident Using 15-km, 3-km, and 500m Grid Models, J. Meteorol. Soc. Jpn. Ser. II, 93, 49-64, https://doi.org/10.2151/jmsj.2015-002, 2015.

Sherlock, V., Connor, B., Robinson, J., Shiona, H., Smale, D., and Pollard, D.: TCCON data from Lauder, New Zealand, 120HR, Release GGG2014R0, TCCON data archive, hosted by CaltechDATA, California Institute of Technology, Pasadena, CA, USA, https://doi.org/10.14291/tccon.ggg2014.lauder01.R0/1149293, 2014.

Shiomi, K., Kawakami, S., Ohyama, H., Arai, K., Okumura, H., Taura, C., Fukamachi, T., and Sakashita, M.: TCCON data from Saga, Japan, Release GGG2014R0, TCCON data archive, hosted by CaltechDATA, California Institute of Technology, Pasadena, CA, USA, https://doi.org/10.14291/tccon.ggg2014.saga01.R0/1149283, 2014.

Staniforth, A. and Côté, J.: Semi-Lagrangian integration schemes for atmospheric models - a review, Mon. Weather Rev., 119, 2206-2223, https://doi.org/10.1175/15200493(1991)119<2206:SLISFA>2.0.CO;2, 1991.

Stavert, A. R., Law, R. M., van der Schoot, M., Langenfelds, R. L., Spencer, D. A., Krummel, P. B., Chambers, S. D., Williams, A. G., Werczynski, S., Francey, R. J., and Howden, R. T.: The Macquarie Island (LoFlo2G) high-precision continuous atmospheric carbon dioxide record, Atmos. Meas. Tech., 12, 11031121, https://doi.org/10.5194/amt-12-1103-2019, 2019.

Stephens, B. B., Miles, N. L., Richardson, S. J., Watt, A. S., and Davis, K. J.: Atmospheric $\mathrm{CO}_{2}$ monitoring with singlecell NDIR-based analyzers, Atmos. Meas. Tech., 4, 2737-2748, https://doi.org/10.5194/amt-4-2737-2011, 2011.

Sussmann, R. and Rettinger, M.: TCCON data from Garmisch, Germany, Release GGG2014R0, TCCON data archive, hosted by CaltechDATA, California Institute of Technology, Pasadena, CA, USA, 
https://doi.org/10.14291/tccon.ggg2014.garmisch01.R0/1149299, 2014.

Takahashi, T., Sutherland, S. C., Wanninkhof, R., Sweeney, C., Feely, R. A., Chipman, D. W., Hales, B., Friederich, G., Chavez, F., Sabine, C., Watson, A., Bakker, D. C. E., Schuster, U., Metzl, N., Yoshikawa-Inoue, H., Ishii, M., Midorikawa, T., Nojiri, Y., Kortzinger, A., Steinhoff, T., Hoppema, M., Olafsson, J., Arnarson, T. S., Tilbrook, B., Johannessen, T., Olsen, A., Bellerby, R., Wong, C. S., Delille, B., Bates, N. R., and de Baar, H. J. W.: Climatological mean and decadal changes in surface ocean $p \mathrm{CO}_{2}$, and net sea-air $\mathrm{CO}_{2}$ flux over the global oceans, Deep-Sea Res. Pt. II, 56, 554-577, 2009.

Tang, W., Arellano, A. F., DiGangi, J. P., Choi, Y., Diskin, G. S., Agustí-Panareda, A., Parrington, M., Massart, S., Gaubert, B., Lee, Y., Kim, D., Jung, J., Hong, J., Hong, J.-W., Kanaya, Y., Lee, M., Stauffer, R. M., Thompson, A. M., Flynn, J. H., and Woo, J.-H.: Evaluating high-resolution forecasts of atmospheric $\mathrm{CO}$ and $\mathrm{CO}_{2}$ from a global prediction system during KORUS-AQ field campaign, Atmos. Chem. Phys., 18, 1100711030, https://doi.org/10.5194/acp-18-11007-2018, 2018.

Temperton, C., Hortal, M., and Simmons, A.: A two-time-level semi-Lagrangian global spectral model, Q. J. Roy. Meteor. Soc., 127, 111-126, 2001.

Thoning, K. W., Tans, P. P., and Komhyr, W. D.: Atmospheric carbon dioxide at Mauna Loa Observatory, 2. Analysis of the NOAA/GMCC data, 1974-1985, J. Geophys. Res., 94, 85498565, 1989.

Tiedtke, M.: A comprehensive mass flux scheme for cumulus parameterization in large-scale models, Mon. Weather Rev., 117, 1779-1800, 1989.

Tolk, L. F., Meesters, A. G. C. A., Dolman, A. J., and Peters, W.: Modelling representation errors of atmospheric $\mathrm{CO}_{2}$ mixing ratios at a regional scale, Atmos. Chem. Phys., 8, 6587-6596, https://doi.org/10.5194/acp-8-6587-2008, 2008.

Tsutsumi, Y., Matsueda, H., and Nishioka, S.: Consistency of the $\mathrm{CO}_{2}$ primary standards in JMA, 12th WMO/IAEA meeting of experts on carbon dioxide concentration and related tracers measurement techniques (Toronto, Canada, 1518 September 2003), Global Atmosphere Watch Report No. 161 (WMO/TD-No.1275), 23-31, 2005.

van der Molen, M. K. and Dolman, A. J.: Regional carbon fluxes and the effect of topography on the variability of atmospheric $\mathrm{CO}_{2}$, J. Geophys. Res., 112, D01104, https://doi.org/10.1029/2006JD007649, 2007.

Verhulst, K. R., Karion, A., Kim, J., Salameh, P. K., Keeling, R. F., Newman, S., Miller, J., Sloop, C., Pongetti, T., Rao, P., Wong, C., Hopkins, F. M., Yadav, V., Weiss, R. F., Duren, R. M., and Miller, C. E.: Carbon dioxide and methane measurements from the Los Angeles Megacity Carbon Project - Part 1: calibration, urban enhancements, and uncertainty estimates, Atmos. Chem. Phys., 17, 8313-8341, https://doi.org/10.5194/acp-17-8313-2017, 2017.

Vermeulen, A. T., Hensen, A., Popa, M. E., van den Bulk, W. C. M., and Jongejan, P. A. C.: Greenhouse gas observations from Cabauw Tall Tower (1992-2010), Atmos. Meas. Tech., 4, 617644, https://doi.org/10.5194/amt-4-617-2011, 2011.

Vogel, F. R., Thiruchittampalam, B., Theloke, J., Kretschmer, R., Gerbig, C., Hammer, S., and Levin, I.: Can we assess a finegrained emission model using high-resolution atmospheric trans- port modeling and regional fossil fuel $\mathrm{CO}_{2}$ observations? Tellus B, 65, 18681, https://doi.org/10.3402/tellusb.v65i0.18681, 2013.

Wang, J. S., Kawa, S. R., Collatz, G. J., Sasakawa, M., Gatti, L. V., Machida, T., Liu, Y., and Manyin, M. E.: A global synthesis inversion analysis of recent variability in $\mathrm{CO}_{2}$ fluxes using GOSAT and in situ observations, Atmos. Chem. Phys., 18, 11097-11124, https://doi.org/10.5194/acp-18-11097-2018, 2018.

Warneke, T., Messerschmidt, J., Notholt, J., Weinzierl, C., Deutscher, N., Petri, C., Grupe, P., Vuillemin, C., Truong, F., Schmidt, M., Ramonet, M., and Parmentier, E.: TCCON data from Orleans, France, Release GGG2014R0, TCCON data archive, hosted by CaltechDATA, California Institute of Technology, Pasadena, CA, USA, https://doi.org/10.14291/tccon.ggg2014.orleans01.R0/1149276, 2014.

Wedi, N. P.: Increasing horizontal resolution in numerical weather prediction and climate simulations: illusion or panacea?, Philos. T. R. Soc. A, 372, 20130289, https://doi.org/10.1098/rsta.2013.0289, 2014.

Wennberg, P. O., Wunch, D., Roehl, C., Blavier, J.-F., Toon, G. C., Allen, N., Dowell, P., Teske, K., Martin, C., and Martin, J.: TCCON data from Lamont, Oklahoma, USA, Release GGG2014R1, TCCON data archive, hosted by CaltechDATA, California Institute of Technology, Pasadena, CA, USA, https://doi.org/10.14291/tccon.ggg2014.lamont01.R1/1255070, 2016.

Wennberg, P. O., Roehl, C., Wunch, D., Toon, G. C., Blavier, J.-F., Washenfelder, R., Keppel-Aleks, G., Allen, N., and Ayers, J.: TCCON data from Park Falls, Wisconsin, USA, Release GGG2014R1, TCCON data archive, hosted by CaltechDATA, California Institute of Technology, Pasadena, CA, USA, https://doi.org/10.14291/tccon.ggg2014.parkfalls01.R0/1149161, 2014a.

Wennberg, P. O., Wunch, D., Roehl, C., Blavier, J.-F., Toon, G. C., and Allen, N.: TCCON data from California Institute of Technology, Pasadena, California, USA, Release GGG2014R1, TCCON data archive, hosted by CaltechDATA, California Institute of Technology, Pasadena, CA, USA, https://doi.org/10.14291/tccon.ggg2014.pasadena01.R1/1182415, 2014b.

Wilson, P. A.: Insight into the Carbon Cycle from Continuous Measurements of Oxygen and Carbon Dioxide at Weybourne Atmospheric Observatory, UK, $\mathrm{PhD}$ thesis, University of East Anglia, Norwich, UK, 2013.

Worthy, D. E., Higuchi, K., and Chan, D.: North American influence on atmospheric carbon dioxide data collected at Sable Island, Canada, Tellus B, 55, 105-114, 2003.

Wunch, D., Wennberg, P. O., Toon, G. C., Keppel-Aleks, G., and Yavin, Y. G.: Emissions of greenhouse gases from a North American megacity, Geophys. Res. Lett., 36, L15810, https://doi.org/10.1029/2009GL039825, 2009.

Wunch, D., Toon, G. C., Blavier, J.-F. L., Washenfelder, R. A., Notholt, J., Connor, B., Griffith, D. W. T., Sherlock, V., and Wennberg, P. O.: The total carbon column observing network, Philos. T. R. Soc. A, 369, 2087-2112, https://doi.org/10.1098/rsta.2010.0240, 2011.

Wunch, D., Wennberg, P. O., Osterman, G., Fisher, B., Naylor, B., Roehl, C. M., O’Dell, C., Mandrake, L., Viatte, C., Kiel, M., Griffith, D. W. T., Deutscher, N. M., Velazco, V. A., Notholt, J., 
Warneke, T., Petri, C., De Maziere, M., Sha, M. K., Sussmann, R., Rettinger, M., Pollard, D., Robinson, J., Morino, I., Uchino, O., Hase, F., Blumenstock, T., Feist, D. G., Arnold, S. G., Strong, K., Mendonca, J., Kivi, R., Heikkinen, P., Iraci, L., Podolske, J., Hillyard, P. W., Kawakami, S., Dubey, M. K., Parker, H. A., Sepulveda, E., García, O. E., Te, Y., Jeseck, P., Gunson, M. R., Crisp, D., and Eldering, A.: Comparisons of the Orbiting Carbon Observatory-2 (OCO-2) $\mathrm{XCO}_{2}$ measurements with TCCON, Atmos. Meas. Tech., 10, 2209-2238, https://doi.org/10.5194/amt10-2209-2017, 2017.

Xueref-Remy, I., Dieudonné, E., Vuillemin, C., Lopez, M., Lac, C., Schmidt, M., Delmotte, M., Chevallier, F., Ravetta, F., Perrussel, O., Ciais, P., Bréon, F.-M., Broquet, G., Ramonet, M., Spain, T. G., and Ampe, C.: Diurnal, synoptic and seasonal variability of atmospheric $\mathrm{CO}_{2}$ in the Paris megacity area, Atmos. Chem. Phys., 18, 3335-3362, https://doi.org/10.5194/acp18-3335-2018, 2018.
Yang, D. X., Liu, Y., Cai, Z. N., Chen, X., Yao, L., and Lu, D. R.: First global carbon dioxide maps produced from TanSat measurements, Adv. Atmos. Sci., 35, 621-623, https://doi.org/10.1007/s00376-018-7312-6, 2018.

Yu, K., Keller, C. A., Jacob, D. J., Molod, A. M., Eastham, S. D., and Long, M. S.: Errors and improvements in the use of archived meteorological data for chemical transport modeling: an analysis using GEOS-Chem v11-01 driven by GEOS-5 meteorology, Geosci. Model Dev., 11, 305-319, https://doi.org/10.5194/gmd11-305-2018, 2018. 